\title{
RIO DE JANEIRO BRAND IDENTITY: AN ANALYSIS OF THE PHYSICAL AND SYMBOLIC DIMENSIONS
}

\author{
iD Daniel Kamlot \\ ESPM; FGV-Ebape; PUC-Rio. \\ Rio de Janeiro, RJ - Brazil. \\ danielkamlot@yahoo.com.br \\ Diego Santos Vieira de Jesus
PUC-Rio. \\ Rio de Janeiro, RJ - Brazil. \\ dsvj@puc-rio.br
}

Study objective: To present an analysis of Rio brand identity in its physical and symbolic dimensions, following the theory according to which the city brand is composed of three different elements: identity, image and reputation, being the brand identity erected from physical and symbolic evidence.

\begin{abstract}
Method: A qualitative method to document analysis was used. It requires data from documents to be reviewed and interpreted in order to extract meaning and understanding, following some steps: bibliographical research; thematic analysis; data collection and evaluation; identification of meaningful data; data interpretation; information analysis; and discussion of findings. We accessed approximately 284 documents, including research papers, e-mails, newsletters, companies and government reports, newspaper articles etc.
\end{abstract}

Main results: The results expose the differences and peculiarities of the physical and symbolic dimensions of Rio brand identity. While in the physical dimension, Rio brand performed poorly in the productive aspect, in the cultural-historical scope the municipal government has sought to expand the network of public cultural spaces, strengthen access to culture. In the political aspect, difficult to create spaces for civil society participation in the formulation of public policies were noticed. Regarding the symbolic dimension, intangible attributes recently have indicated unsatisfactory levels of esteem, admiration, and trust of Rio's residents for a successful city brand, with important initiatives concerning the promotion of the city connections and potentialities strongly based on innovation and sustainability. Together, these dimensions can strengthen the identity of Rio's brand, indicating suitable instruments for the city development.

Theoretical/methodological contributions: The main contributions of this study are to explore the physical and symbolic dimensions of a city brand identity and to interpret it in detail, considering the recent evolution of the city. It also contributes to marketing literature, addressing elements of the city brand rarely discussed theoretically, such as the physical and symbolic dimensions of a city brand identity and its components.

Relevance/originality: The study of the physical and symbolic dimensions of a city brand identity is very rare in marketing literature, so this investigation provides a new way to understand the conjuncture of a city - through its productive, political, and cultural-historical dimensions, and also considering its connections, potentialities and intangible attributes -, which can help in future studies related to the interpretation of the place brand identity and this field of knowledge.

Managerial and social implications: This study provides subsidies and knowledge that facilitate the design of public policies based on the understanding of the city's current identity.

Keywords: Rio de Janeiro; Brand identity. Physical dimension. Symbolic dimension. Place brand.

\section{How to cite the article}

American Psychological Association (APA)

Kamlot, Daniel., \& Jesus, D. S. V. (2022, Jan./Mar.). Rio de Janeiro brand identity: an analysis of the physical and symbolic dimensions. Brazilian Journal of Marketing, 21(Special Issues), 64-87. https://doi.org/10.5585/remark.v21i1.20344. 


\section{Introduction}

To conceive a brand, it is necessary to understand the consumer's mind in order to ensure the product's own characteristics are not limited only to its merely functional concepts (Nunes \& Haigh, 2003). When creating the personality of a brand and its relationship with the consumer, a meaning or value for the product emerges in a way that stimulates the desire in the consumer and creates a positive perception for the image of what is offered. The brand would thus evolve from functionality to loyalty, passing through appreciation.

According to Ries and Ries (2009), a brand becomes as powerful as its ability to influence buying behavior. So companies do not sell candies, glasses or motorcycles. They sell feelings and sensations, and they raise identification. The concept of brand, then, is really important for a company. Like any heritage property, it should also be subject to constant maintenance procedures and even rejuvenation.

The performance of a brand is also directly linked to how it meets the consumer psychological and social needs (Kamlot, 2013; 2017), which are responsible for driving the buying decision, at least in part. From there, the brand can provide a meaning for the client, who will form in his/her mind the image of the brand, causing - or not - recognition and appreciation of it, not only restricted to the financial aspect, but to the "set of economic, functional and psychological benefits that consumers expect from a particular offer" (Kotler, 2012, p. 40).

As explained by Cheverton (2012), one of the greatest potentialities of a valuable brand is that it exerts all its power within the consumers' minds, what seems to be aligned with the perception of brand image. Several times an emotional connection between brand and consumer is established. According to the consumer's perception of the brand, a relationship between both occurs, contributing in a positive or negative way, depending whether he/she likes or not the brand image formed, which will be decisive in terms of loyalty and fidelity.

Franzen and Bouwman (2001) perceive brands as living entities in a mental world, as an array of memory elements, grouped and shaped by certain "schemes". In this mental world of brands, brand memory items are usually obtained unconsciously; on the other hand, decisions regarding the brand are not fully conscious.

Presently, brands are noticed as an important tool not only for entrepreneurs and businesses in general, but also for places. Despite its intangibility, a brand can be understood as an important strategic asset, responsible for differentiation, which motivates consumers to 
be (more) interested in some product or service offered to him (Kotler \& Gertner, 2002), and the same is noticed concerning place brands.

Considering the "general agreement among academics and practitioners that places can be branded in much the same way as consumer goods and services" (Caldwell \& Freire, 2004, p.50-51), this article will focus on the brand identity related to the city of Rio de Janeiro, one of the most famous and relevant Brazilian cities. The objective is to present an analysis of Rio brand identity in its physical and symbolic dimensions, following the theory defined by Reis (2018) - according to which the city brand is composed of three different elements: identity, image and reputation, being the brand identity erected from physical and symbolic evidence.

The main contribution of this paper is related to a broader comprehension of the connections among different dimensions of the city brand and the its potential to define adequate public policies, considering the evaluation of physical and symbolic aspects inherent to the city. More specifically, the dimensions that encompass physical and symbolic evidence help in defining the links between the city and its inhabitants, in order to assist managers to explore the city potential for the development of infrastructure, environment, engagement and social planning issues.

\section{Theoretical references}

\section{Brands and its importance}

The literature about branding is usually focused on companies and corporations from different sectors, locations and sizes. Although brands could create value and consolidate trust in the company, helping to raise its profits (Kapferer, 2008), it is not possible to assume this is true for all areas of operation.

The importance of brands is growing, both for manufacturers and for consumers who intend to purchase a product. The value of many brands already accounts for most of the market value of several companies (Sampaio, 2006), thus indicating the growing relevance of this intangible asset for businesses in general. Also, a strong brand can be responsible for a huge contribution to a place, such as a city, a nation or a specific location (Hanna et al., 2021), and hold dimensional benefits that makes it easy to understand what the citizens value in a place brand (Mariutti \& Giraldi, 2021).

It is interesting to note that brands were developed for a number of different purposes. The initial one was to confer legal protection under the inventor's patent; the second was to ensure quality and homogeneity after personal contact between buyer and seller diminished as 
a result of the growth of industrialization. The third purpose stems from the need for corporations to distinguish their products. Until today, manufacturers do everything possible to differentiate their brands, in order to lead consumers to believe they are unique, as a strong brand reduces the probability of substitution (Jones, 2004).

Changes in the market have increased the power of brands. From the moment a brand lends value to the product, it gains greater relevance, as it has a prior relationship with the consumer, including the good experiences obtained with that product (Sampaio, 2013). This is observed not only for products, but also for ideas, behaviors, services and places (Kamlot \& Fajardo, 2019). Considering that a brand image relates to the consumer's perceptions regarding a brand promoted by the interaction of the affective, cognitive, and evaluative processes in a customer's mind (Lee et al., 2019), it is possible to notice that when a customer trusts a brand, its importance grows, leading to commitment and affection to this same brand (Sanny et al., 2020).

\section{Brand perception and place brands}

Perception can be understood by how individuals see the world around them (Schiffman $\&$ Kanuk, 2009). Two people can be subjected to the same stimuli under the same apparent conditions, but the way each one recognizes and interprets each stimulus or phenomenon is an individualized process, based on each person's needs, values and expectations.

A brand becomes as powerful as its ability to influence purchasing behavior (Ries \& Ries, 2009). Hence the importance of realizing that a brand, its name or symbol on a package, for instance, cannot be evaluated in the same way as a brand name in the mind of the potential consumer. For a brand to gain relevance and survive in today's competitive market, it is recommended to have a vast knowledge of people's emotional needs and desires.

Consequently, the biggest challenge is precisely to define a brand through a set of meanings for it, and not just its name and symbol, as, thus, the chances of greater involvement with it will be much greater, which stems from the emergence of opportunities to realize the advantages and benefits that such a brand can offer - the so-called brand value (Tybout \& Carpenter, 2013).

In addition, given that brands have different purposes for different contexts, specific criteria and planning must be defined for each situation. In the case of places, the brand has been increasingly relevant, and to develop some place branding is more difficult when compared to products or services (Ocke \& Ikeda, 2014), so the concept of place brand 
perception (Figure 1) is relevant for any planning. According to Braun and Zenker (2010, p.5), to understand what place brand perception is about it is essential to notice that a brand "is not in reality the communicated expression or the 'place physics', but the perception of those expressions in the mind of the target group(s)". The authors also emphasize that "these perceptions lead to brand effects such as identification, satisfaction or other effects like information-seeking bias, commitment and intention to stay", as shown in Figure 1.

\section{Figure 1}

\section{Concept of Place Brand Perception}

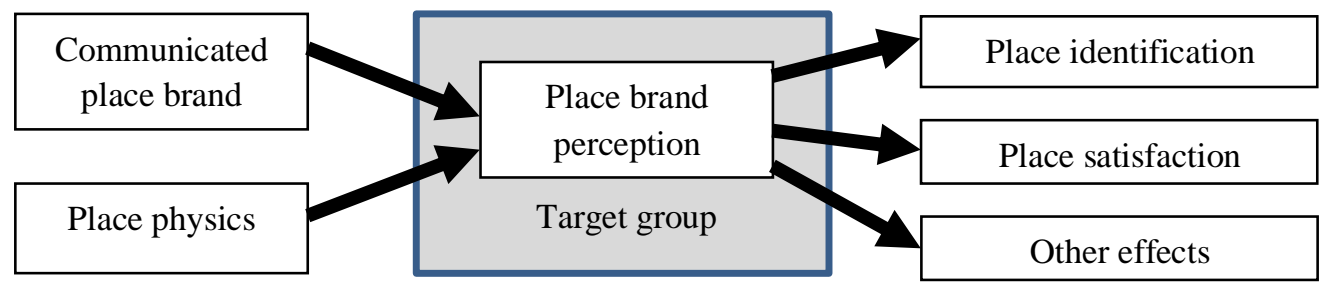

Source: Braun \& Zenker, 2010

Jacobsen (2012) established a conceptual model which comprises place brand actuators that are related to the place customer behavior, shown in Figure 2. The author explains that some brand attributes are associated with opportunities of operational brand management. Regarding the dimensions mentioned by Jacobsen (2012), the tangible dimension of place brand attributes comprises quality, impression, and promotion, and the intangible dimension embraces awareness, heritage, image, personality, reputation and confidence.

\section{Figure 2}

Concept of Place Brand Perception

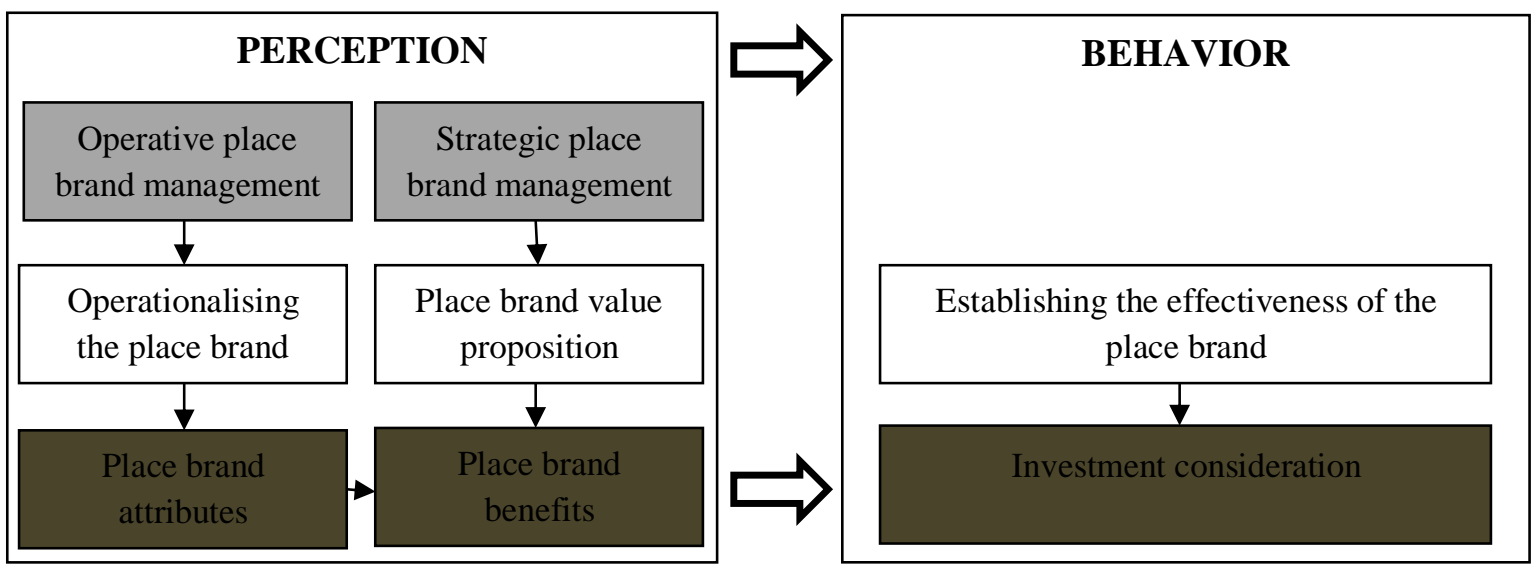

Source: Jacobsen, 2012 
We can notice the place brand perception relates to many different attributes. Braun and Zenker (2010) mentions that because of the varying knowledge levels of the consumers and their different expectations for a location, brand perception varies significantly amongst target groups. Thus, a concept that helps the analysis is place brand identity, explained below.

\section{Place brand identity}

To understand the meaning of place brands, it is necessary to investigate the literature related to this subject, which may differ among authors, specifically when it comes to the definition of the term. Scholars differ greatly on the definitions to be "accepted" regarding place identity and place brand, and sometimes there are confusion between the contents of place marketing and place brand, often lacking a consistent usage of the terms (Zenker, 2011). Table 1 shows the definitions considered relevant in this study.

\section{Table 1}

\section{Relevant Definitions: Place Marketing, Place Brand and Brand Identity}

\begin{tabular}{|c|c|}
\hline Definitions & Author(s) \\
\hline $\begin{array}{l}\text { [A place brand can be understood] as a name, symbol, logo, word mark or other graphic } \\
\text { that both identifies and differentiates the destination; furthermore, it conveys the promise } \\
\text { of a memorable travel experience that is uniquely associated with the destination; it also } \\
\text { serves to consolidate and reinforce the recollection of pleasurable memories of the } \\
\text { destination experience. }\end{array}$ & $\begin{array}{l}\text { Ritchie \& Ritchie } \\
\text { (1998, p.103) }\end{array}$ \\
\hline $\begin{array}{l}\text { [Place marketing is defined as] the coordinated use of marketing tools supported by a } \\
\text { shared customer-oriented philosophy, for creating, communicating, delivering, and } \\
\text { exchanging urban offerings that have value for the city's customers and the city's } \\
\text { community at large }\end{array}$ & $\begin{array}{l}\text { Braun (2008, p. } \\
43)\end{array}$ \\
\hline $\begin{array}{l}\text { [A place brand is defined as] a network of associations in the consumers' mind based on } \\
\text { the visual, verbal, and behavioural expression of a place, which is embodied through the } \\
\text { aims, communication, values, and the general culture of the place's stakeholders and the } \\
\text { overall place design }\end{array}$ & $\begin{array}{l}\text { Braun \& Zenker } \\
(2010, \text { p. 4) }\end{array}$ \\
\hline $\begin{array}{l}\text { Place branding is tied to its ecosystem (Bergvall, 2006), both human and natural, and is } \\
\text { dependent on the relationships between people, communities, place, and experience. } \\
\text { These relationships create and reveal idiosyncrasies and cultural underpinnings } \\
\text { (Bergvall, 2006) that would determine the nature of ownership. A place brand by nature } \\
\text { belongs to the place and its people. This genuine and foundational relationship, even } \\
\text { before conscious claims by the community, influences all aspects of the brand, since the } \\
\text { creation of meanings and values constitutes the basis of ownership. }\end{array}$ & $\begin{array}{l}\text { Aitken \& } \\
\text { Campelo (2011, } \\
\text { p.917) }\end{array}$ \\
\hline $\begin{array}{l}\text { Place marketing is analyzed in terms of different approaches characteristic of its } \\
\text { multidisciplinary nature. Most studies seek to conceptualize it with reference to the } \\
\text { sustainable development of the place, aiming to satisfy target segments, identified as } \\
\text { current and potential, with the in order to create, or generate, positive value for those } \\
\text { involved, as well how to strengthen the attractiveness and competitiveness of a place } \\
\text { with a focus on foreign and domestic markets. }\end{array}$ & $\begin{array}{l}\text { Ocke \& Ikeda } \\
\text { (2014, p.672) }\end{array}$ \\
\hline
\end{tabular}




\begin{tabular}{|l|l|}
\hline \multicolumn{1}{|c|}{ Definitions } & Author(s) \\
\hline $\begin{array}{l}\text { The brand identity dimension is divided into physical evidence and symbolic evidence of } \\
\text { the brand. The physical evidence of the brand (...) is composed of the elements that } \\
\text { make up the productive, political and cultural-historical dimension of the brand. The } \\
\text { symbolic evidence of the brand is formed by identifying the elements that make up the } \\
\text { intangible attributes, the connections with the place and the brand's potentialities. } \\
\begin{array}{l}\text { The dimensions of the brand's identity and image are mediated by the communicational } \\
\text { dimension, which acts as a two-way flow between the dissemination and projection of } \\
\text { the brand's identity elements in audiences and the incorporation and reinterpretation of } \\
\text { the brand's identity from the images that are formed in these same audiences. }\end{array}\end{array}$ & Reis (2018) \\
\hline $\begin{array}{l}\text { Place brand represents a network of associations in the minds of the audiences, based on } \\
\text { the visual, verbal and behavioral expression of a place, which encompasses the purposes, }, \\
\text { communications, values and general culture of the audiences involved, as well as the } \\
\text { urban space of the place. }\end{array}$ & Mariutti (2019) \\
\hline
\end{tabular}

Source: The authors.

There are many models used to analyze a city. Reputation Institute (2014), for example, created a model - called City RepTrak Pulse - which is focused on reputation, economic impacts, and other characteristics, such as the balance between reality and the perception people have of the place. In this sense, two different scopes of analysis are integrated: one emotional and another, rational. Saffron (2013) created the Placemark Thermometer, for which some factors, which delineate the brand and influence people's perception, were defined, being composed of the observable and measurable characteristics of the city to assess how strong the brand can be. And the Cities in Motion Index (Berrone \& Ricart, 2016), which presents an approach to management of cities based on four items: sustainable ecosystems, innovative activities, equality between citizens and territorial connectivity.

Considering the attributes of these models, we can notice they aim to elaborate rankings and offer consultancy services to improve the position of cities in these same rankings. Therefore, they are directed not to many distinct areas, but to specific sectors of activity, impairing a more comprehensive analysis.

That's why, in this article, we will focus on Reis (2018) model and definition, in which the author states the city brand is composed of three different elements: identity, image and reputation, with the brand identity being built from physical and symbolic evidence, explained below. This is a more comprehensive model, which can help in the present research due to its suitability.

\section{Physical evidence}

The physical evidence of the brand's identity is defined by a network of elements that characterize the place and materialize its singularities and differentials. In this aspect, the brand 
is not only a producer of information but a promoter of relationships. To elaborate the physical evidence, elements related to the productive dimension of the territory, the political dimension and the historical-cultural dimension are incorporated into the identity, since "political, historical, social and cultural elements also contribute to the essence of a place brand" (Skinner, 2011). The productive dimension refers to the articulation of industries and service providers existing in the place with their vocations. This articulation provides better technological and economic development, a stable and low-risk economy, as well as more favorable environments for business. As a result of the articulation of different existing industries and services, the productive dimension also incorporates the possibility of high-quality local products and services, with better-known brands. The political dimension refers to the existence of spaces for participation, the political structure of the place and the recognition of an efficient administration in place. It also relates to the presence of the city and its leaders and personalities on the international stage. This dimension considers the existence of areas for social participation in the formulation, implementation and inspection of public policies and public transparency practices, as well as the participation of local leaders in international forums and institutions aimed at promoting the city in the external sphere. The cultural-historical dimension incorporates the preservation and recovery of existing historical facts and places, as well as local cultural references, the feeling of belonging and the local contribution to global culture. Leisure and cultural facilities represent this dimension and should promote the uniqueness of the place. This dimension also encompasses events with international visibility held in the city (REIS, 2018).

\section{Symbolic evidence}

Symbolic evidence refers to the emotional dimension that arises from experiences with the place and existing expectations. In this aspect, the brand is a producer of meanings and a promoter of emotions. To elaborate the symbolic evidence, elements related to the intangible attributes, the connections established in it and the potential of the place are incorporated into the brand's identity. Intangible attributes refer to people's experiences with physical evidence. They can encourage positive associations with the city and the relationships that arise between audiences through the brand. Esteem, admiration, and confidence people feel in the place are embodied in these attributes. Connections based on experiences with the place are a dimension of the city's brand, made up of face-to-face and virtual spaces that encourage interconnections between people and the place. Events are strategies with high power to generate connections. 
Here, too, the recognition of the place in the international media is inserted, providing new connections. The potentialities refer to the elements of the brand that are still expectations and perspectives for the future and to the improvements resulting from the elements present in the physical evidence, regarding innovation, entrepreneurship, and sustainable development (Reis, 2018).

Reis (2018) states that the image refers to the communication of the city brand, which is responsible for giving visibility, establishing correlations between the elements that are associated with physical and symbolic evidence. The transition between the realm of identity and the realm of brand image occurs through deliberate and spontaneous communicational efforts, generating varied perceptions in people's memories. Different types of communication make up the communicational dimension of the city brand based on the nature of its messages, the diversity and complexity that a city brand brings in its communication to become adherent both to the place and to the audiences that relate to it. They are: engagement communication; public service communication; communication of new business; communication with international visibility; and communication of public opinion.

Although the procedure of creating reputation is not perfectly specified (Gammelsæter, 2017), Delgado-García et al. (2017, p.1099) define it as "the aggregation of a single stakeholder's perceptions of the capacity of the city to meet demands and expectations of many city stakeholders". So, it is relevant to notice that cities relate to many distinct stakeholders whose claims are varied, being understood as locations not only to live, but also to work, and have fun. The city also provides many services, depending on the inhabitants' needs. It can also be seen as a location for businesses and entrepreneurs to locate, trade, and invest. Besides, the city provides a mix of culture, education, and entertainment for tourists (Van den Berg \& Braun, 1999). Reis (2018) indicates the city reputation refers to the sum of the various perceptions that different stakeholders have of the brand over a longer period, enabling them to make a judgment about how management takes place. In this case, the reputation of the city brand is a process of building perceptions of different audiences of a brand in relation to experiences with the city for a longer period of time.

\section{Method}

This research was structured in order to follow a logical and reflective arrangement, emphasizing the interpretation of the contents found in several sources (Severino, 2018). After understanding the context of Rio de Janeiro city in the last 3 years (from 2018 to March, 2021), 
we employed Bowen's (2009) qualitative method to document analysis, which requires data from documents to be reviewed and interpreted in order to extract meaning and understanding, producing empirical knowledge.

Therefore, the procedure followed the subsequent steps: (1) bibliographical research, (2) thematic analysis, (3) data collection and evaluation, (4) Identification of meaningful data and relevant information definition, (5) data interpretation according to document analysis, (6) information analysis (related to the physical and symbolic dimensions of Rio brand), and (7) discussion of findings

The sample obtained consists of documents and texts related to the situation and evolution of Rio in the last three years, generated by government entities, private institutions and scholars. This allowed a document analysis, appropriate to provide access to relevant information and a broad range of data related to the physical and symbolic dimensions of the city brand, which aided in contextualizing the study within its field (Bowen, 2009).

We accessed approximately 284 documents of different kinds, such as companies and government reports, research papers, e-mails, newsletters and many others. The documents were obtained through contact with public services, autarchies, libraries, researchers and scholars. The inclusion criteria were relatively simple: the core of the document should be related to some of the dimensions that make up Rio de Janeiro brand identity, which is divided into physical and symbolic evidence (as explained in Table 1). We could collect hundreds of different pieces of information, but after evaluation, less than 300 of them were considered adequate for the research. Based on these, data interpretation was performed. We estimate that half of the researched documents was academic, and the other half was divided into government and private ones.

\section{Analysis and discussion of the results}

Regarding the physical evidence of the brand's identity, the document analysis shows that elements that make up the productive dimension of the Rio de Janeiro brand performed poorly. Since 2017, industries and service providers in the city have been weakened because of a political-economic crisis, which created a non-incentive to foster local vocations, such as products associated with the city's brand. Among the factors that reflect this crisis, it is worth highlighting the worsening of unemployment and the general increase in the price of products, largely fueled by the higher level of violence in the state of Rio de Janeiro, particularly in its capital. Focusing specifically on issues related to employment, even though the industry has led 
to a positive performance of employment levels in Brazil in 2017 compared to 2016, Rio de Janeiro was the national exception. Until September 2017, there had been a reduction of 4,769 jobs in the state, mostly in the capital. The analysis of the General Register of Employed and Unemployed People indicated that Rio de Janeiro was the municipality in the state that closed the most formal vacancies in 2017. The oil crisis, the commitment of contractors after the Lava Jato operations, the indebtedness of Petrobras and the fiscal crisis in the State of Rio de Janeiro explain the alarming situation, which led to the closing of jobs and demonstrated a growing disarticulation of industries and service providers in the city with its natural vocations, which negatively impacted technological and economic development, economic stability and existing businesses in the city, as well as the level of employment. According to the Municipal Department of Finance, the drop in the number of jobs in the city had a direct impact on the collection of ISS, the municipal tax on services. The generalized crisis that befell employment in the state of Rio de Janeiro reflects the greater economic instability and greater risk associated with existing businesses, in addition to discouraging the generation of new ventures and the creation of job vacancies, including in the sectors related to the city's vocations (Jesus et al., 2019).

Since the first quarter of 2020, the new coronavirus pandemic has led to the temporary and permanent closure of businesses, the reduction of activities of those who survived through measures of social distancing, the limitation of the number of people in establishments and the increase in the number of unemployed and underemployed people. Unemployment in the context of the pandemic hit a record in the state of Rio de Janeiro in September 2020, with more than 1.2 million unemployed people, around 405,000 more than registered in May of the same year. The economy of the city and state of Rio de Janeiro could recover after vaccination against Covid-19, which would make the employment curve grow again as of the second half of 2021. However, the 2021's first semester was still difficult, marked by the impact of the end of emergency aid, a benefit instituted in Brazil by Law 13.982/2020, which provided for the transfer of 600 reais a month (initially for three months) to informal and low-income workers, individual micro-entrepreneurs and individual contributors to the National Social Security Institute to minimize the economic impacts caused by the pandemic. In early September 2020, the Federal Government announced the payment of four more instalments of 300 reais until December 2020. From 2021, it was expected that sales would fall even further, unemployment would increase due to the lack of consumers, money would circulate less in the economy, and commerce would have to reduce its costs even more (Moura, 2021). In addition to the return of 
the aid, specialists defended the return of the work contract suspension program and the workload reduction, which would have prevented a much larger mass of unemployed people. In the specific case of the city of Rio de Janeiro, one of the areas whose economic activity was most affected by the pandemic was Rio's downtown. After the gradual growth with the advent of Porto Maravilha, at the beginning of 2021, the region had many empty properties, several homeless people, lack of public safety, destruction of historic heritage and insecurity for new investments in the face of the severe economic crisis. In January 2021, Mayor Eduardo Paes launched the Reviver Centro plan, which seeks to stimulate the social, economic, and urban recovery of the downtown area by permitting new uses to encourage the construction of new homes and the retrofit of commercial buildings, transforming them into residential or mixed buildings (Diário do Rio, 2021).

In the political dimension of Rio's brand identity, some elements made it difficult to create spaces for civil society participation in the formulation of public policies in the city of Rio de Janeiro. The economic recession - combined with the retraction in the activities of the oil industry and the drop in revenue - led to the growing pauperization of the population, which was further aggravated by the corruption disseminated by the political apparatus of the state of Rio de Janeiro. This spread has become evident since the arrest of former governors Sérgio Cabral Filho, in 2016, and Luiz Fernando Pezão, in 2018, in the context of Operation Lava Jato, as well as of former secretaries and counsellors of the Court of Auditors. The situation led not only to a shortage of funds for the payment of salaries of state employees, but to the gradual collapse of state government programs such as the Emergency Care Units (UPAs, in the acronym in Portuguese) and the Pacifying Police Units (UPPs, in the acronym in Portuguese) throughout 2017. Even though groups of citizens have mobilized politically in the face of such a situation - including through the holding of public events held throughout the city, as civil servants in the education and health sectors in 2017 - such engagement has had little political effect, as it ran into the permanence of political coalitions in the municipal Executive and Legislative powers, which indicated the lack of resources for salary payments and new investments in the city. In addition, the unfavourable economic and political situation caused crime to spread throughout the city, so areas of engagement of citizens, such as community associations, had their access blocked in the dispute between the police and criminals. Although the UPPs' bases remain in the places where they were installed, these places have been gradually reoccupied by criminal factions since the end of the 2016 Olympic Games. Given the lack of a specific policy for public safety, the government of the state of Rio de Janeiro returned 
to focusing on the fight against drugs throughout 2017, which mainly victimized the black and low-income population. The attacks on drug traffickers have recovered a scenario of interruption of public and private education and commercial services in the regions dominated by the factions. The situation of widespread violence made mobilization difficult in communities affected by the war between state forces and criminal factions. In the first quarter of 2018, a series of episodes of violence during Carnival - particularly in the city of Rio de Janeiro and most of them against women - influenced the decision taken by the Federal Government to carry out an intervention in the state of Rio de Janeiro. This decision brought about a change in the political structure dealing with the theme of public security, which directly impacts the political dimension of the brand identity in the city of Rio de Janeiro. It translated into an official attempt to restore the stability of public order in the city and the rest of the state. The curtailment of social participation practices in the formulation of public policies in the city of Rio de Janeiro was evident with the murder of PSOL councillor Marielle Franco and her driver Anderson Gomes in March 2018. Franco was a defender of the rights of the women, the LGBT population, the black people, and the population of the city's favelas. At the City Council, she was part of a commission whose objective was to monitor federal intervention in Rio de Janeiro and was chosen as its rapporteur in February 2018. Franco was critical of federal intervention, police abuses and human rights violations. The national and international press highlighted Franco's death as a targeted attack, criticizing police violence in the city and state of Rio de Janeiro (Jesus, 2019).

The crisis in the political dimension of the physical evidence of the Rio Brand's identity became even more alarming because of the worsening of the precariousness of the local political structure and the recognition, by a large part of the population, of the inefficiency of the administration of Mayor Marcelo Crivella. After seeking agreements aimed at maintaining his position in the face of impeachment attempts, Crivella did not significantly curb unnecessary expenses with commissioned positions and the creation of undersecretaries. He ended up in jail in December 2020, just days before he left office. The arrest was the result of an action that investigated a corruption scheme in the municipal administration and revealed the existence of a "Bribery HQ" in City Hall. The joint operation of the Public Ministry of Rio de Janeiro with the Civil Police pointed out that businessmen paid to have access to contracts and receive amounts owed by the municipal management $(\mathrm{G} 1,2020)$.

The Covid-19 pandemic highlighted the weakness in the management of the public health system. In December 2020, the public health network in the city of Rio de Janeiro was 
already collapsing, as hundreds of people were waiting for an ICU bed in the metropolitan region. In the private network, the situation was also worrying, because almost all intensive care beds in the city were occupied. Hospitals suffered not only from overcrowding, but also basic care. The increase in deaths outside hospitals in mid-October 2020 was an indication that there was a lack of health care for cariocas due, in large part, to the demobilization of beds after the months with greater numbers of Covid-19 cases and deaths in the city. In addition to deaths that could be caused by the novel coronavirus, Fiocruz's experts pointed out that many occurred due to chronic diseases, such as diabetes and hypertension, indirectly caused by the pandemic due to the restriction of access to healthcare. One of Fiocruz's concerns was that the increase in cases of the disease happened close to the end of the year celebrations and warned that the lack of assistance could worsen if there were no reinforcement in the hospital structure (Grinberg, 2020). The clash between the guidelines of the Presidency of the Republic and the Ministry of Health and those of local governments such as city halls sent contradictory signals to the Brazilian population during the novel coronavirus pandemic. Many debates arose on social networks about the need to maintain measures of social distancing or to return to normal economic activities. With the intensification of the pandemic and the extension of restrictive measures, a large part of the population began to disregard sanitary measures and, with the premature opening of commerce in several regions of cities such as Rio de Janeiro, it generated agglomerations, especially in bars, restaurants, and nightclubs (Jesus, 2021).

Some events involving political leaders in the city and state of Rio de Janeiro made it difficult to create a more intense articulation between the local level and other levels of government, as in the impeachment trial of the governor Wilson Witzel. Witzel was removed from office in August 2020, suspected of corruption. The criminal scheme was discovered due to irregularities in the hiring of field hospitals, respirators, and medicines to fight the novel coronavirus pandemic. The Attorney General's Office stated that the government of the state of Rio de Janeiro had established a bribe scheme for emergency hiring and the release of payments to social organizations that provided services to the government (Barreira, 2021). It is also worth remembering the developments related to the "rachadinha" scheme in Flávio Bolsonaro's office in the Legislative Assembly, in which parliamentary advisors returned part of their salary to the politicians who employed them. In November 2020, Senator Bolsonaro was denounced for the crimes of embezzlement, money laundering, criminal organization, and misappropriation by the Public Ministry of Rio de Janeiro. Former military policeman and former adviser Fabricio Queiroz - a kind of handyman of the Bolsonaro family and considered 
the financial operator of the group - and 15 other former advisers were also formally accused by the Public Ministry. Bolsonaro was accused of embezzling part of the salary of ghost advisors (Betim, 2020).

In the cultural-historical dimension, the municipal government has sought until 2016 to expand the network of public cultural spaces, strengthen access to culture and, with regard specifically to the creative economy, focus on supporting production, marketing, infrastructure, and training. The dissemination of the city's image abroad was based on large-scale sociocultural events linked to the creative economy, such as the samba school parades during Carnival. However, such dissemination was severely hampered by the systematic attempt to depreciate numerous cultural expressions of the city of Rio de Janeiro by former Mayor Marcelo Crivella - such as those associated with Afro-Brazilian culture and the LGBT+ population and the multiple impacts on the creative economy of city by measures of social distancing, closing of cultural spaces during the new coronavirus pandemic and non-realization of cultural events that are important for the city's economy, but generate agglomerations. The economicfinancial crisis had already reduced the amount of funds to be used in the maintenance of cultural facilities that promote the uniqueness of Rio's regions and the payment of employees who work in these facilities. In the context of cultural events, the fiscal adjustment promoted by Mayor Marcelo Crivella affected the finances of some of the city's main cultural events, such as the LGBT Pride. Crivella has been accused by civil society groups of letting his religious convictions interfere with administrative decisions (Jesus et al., 2019).

The creative economy of the city of Rio de Janeiro was impacted differently by the new coronavirus pandemic. Many creative professionals lost their jobs due to the crisis because some projects were delayed or cancelled. With the hiring hiatus, many creative professionals said they would not be able to live for long without any work, although many sought to live off their savings or government aid. For example, the Aldir Blanc Law - Blanc was one of the first artists killed because of the pandemic - required the Brazilian government to transfer three billion reais to the states and municipalities to be invested in emergency actions to support the cultural sector, including the cost of monthly emergency income for culture workers. The Law allows federal financial institutions to create special credit lines and grant special conditions for the renegotiation of debts (SECEC-RJ, n.d.). Some creative sectors such as theatre, dance, live entertainment, events, museums, galleries, and tangible cultural heritage were widely exposed to the pandemic and experienced substantial losses throughout 2020, which led to several ventures going bankrupt. Other sectors such as fashion, visual arts, gastronomy, and crafts also 
had losses, but they are preparing for a slow recovery with the reorganization of their production chains and the creation of products and services in response to changes in consumer behavior with the incorporation of virtual learning, logistics, and delivery methods. Some sectors of the low-touch economy seemed less exposed to Covid-19, such as music recording and radio, digital content production and e-sports. The consumption of products from these sectors remained relatively stable or even grew (Jesus, 2020; Jesus et al, 2020).

This reality is combined with a pre-existing framework of deficiencies in management and the lack of technical knowledge in supervisory bodies, which lead to the physical and symbolic decay of the city's cultural heritage. Particularly in Rio's downtown, the degradation and destruction of the historical heritage and the insecurity for new investments in the light of the serious economic crisis became more intense. The preservation of the cultural heritage is fundamental to the development of a creative city like Rio de Janeiro, as it can emphasize the arts, differentiated services and entertainment to attract creative professionals; reappropriate, restore, and rehabilitate the present aiming at a future of renewed social relations in the city; and lead to the apprehension of traditional knowledge, transversal to several fields, aiming at socioeconomic development. However, the deficiencies in the management and the scarce technical knowledge in supervisory bodies lead to the physical and symbolic decay of the cultural heritage in the city. Furthermore, the neglect and depredation of the tangible heritage and the devaluation of the intangible heritage may be indicative of the lack of an intense heritage education process (Jesus, 2017).

Regarding the symbolic evidence, the intangible attributes after the 2016 Olympic Games have already indicated unsatisfactory levels of esteem, admiration, and trust of Rio's residents for a successful city brand. Many residents indicated that they were dissatisfied with the city and considered the possibility of living elsewhere. Among the main reasons why they had not moved yet, the main causes mentioned by these residents were the fear of leaving work; the lack of money to cover the costs of moving; maintaining ties with the family; conducting studies; and the presence of friends in the city. Among the main negative points of the city, residents often point out the lack of public safety; the bad traffic conditions; the high cost of living; pollution of the air, streets, rivers, sea, and lagoons; and the precarious conditions of services in general (Veja Rio, 2016). With the Covid-19 pandemic, there was a great increase in the confidence of Brazilians in general - and of cariocas in particular - in relation to the Unified Health System (SUS, its acronym in Portuguese). One reason for this may have been the greater knowledge of Brazilians in general about what the system is and what the system's 
attributions are. Teleport Cities' Quality of Life report, which assesses 266 cities around the world, has yielded some important results. When evaluating the cost of living, the capital of Rio de Janeiro is ranked 62nd (out of a total of 248 cities evaluated). Regarding Rio's economy and taxation, the city drops in the ranking, occupying the 253rd position among 263 cities and the 237th among 266 cities, respectively. The only positive highlights are seen in the leisure and culture (in which Rio is ranked 18th, among 264 cities) and outdoor spaces, ranked in 34th, among 266 cities (Teleport, 2020). The confidence of industrial entrepreneurs showed 59.8 points in January 2021, a reduction of 0.6 points in relation to the last month of 2020, after seven consecutive increases. Such a drop is apparently due to the resurgence of the effects of the Covid-19 pandemic (Firjan, 2021). Even though the report refers to the state of Rio de Janeiro, it is possible to assume that in the capital the trend is maintained.

There were important initiatives regarding the promotion of the connections in the city. In September 2017, the federal, state, and municipal governments and the private sector released a calendar for events in the state and its capital during 2018, with the aim of reversing the serious financial and social situation. The attempt to leverage tourism proved to be one of the main initiatives to increase tax collection and explore the socioeconomic vocations of the city and the state of Rio de Janeiro. The program brought cultural, sports, and corporate events with potential socioeconomic impact to Rio de Janeiro. Among some of the main events, it is worth highlighting the city's Street Carnival, the Samba School Parades, the International Season at the Municipal Theater, the Rio Content Market, the Carioca Fashion Circuit, the LGBTI-Rio Pride, the Anima Mundi Festival, the XGames and the New Year's Eve. The expectation was that the events could contribute to the generation of face-to-face and virtual spaces that would stimulate connections between people and the city; however, for such connections to occur, it would first be necessary to establish an environment of security and trust so that residents and tourists could move around the city and go to such events, which became unfeasible with the increase in the number of crimes against life and the heritage. Throughout 2020 and early 2021, it was possible to notice a dramatic change in activities related to tourism, shows and the agglomeration of people, especially from March 2020, when the quarantine derived from the Covid-19 pandemic has closed several other establishments. In May 2020, the state undersecretary for megaevents, Ruan Lira, believed that it would be possible to hold large events in Rio de Janeiro in mid-October/November, and possibly this perception was shared by many cariocas. Unfortunately, Rio's authorities decided to postpone Carnival and then to cancel it permanently in 2021, as well as the New Year's Eve 2020/2021 
fireworks display in Copacabana, something that had never happened before. The street blocks in Rio did not parade either, in a decision ratified in October 2020 by the president of Riotur, Fabrício Villa Flor, together with infectious disease doctors, public safety specialists, and representatives of the street Carnival blocks. Furthermore, many live shows were replaced by virtual live performances by artists and bands (Exame, 2020).

The Rio Brand's potentialities are predominantly based on innovation and sustainability. The development of innovation is fundamental to a creative city like Rio de Janeiro, since the idea of innovation can be defined as the effective introduction and application of unprecedented processes and products in an organization or society, intended to benefit its stakeholders, as well as individuals and society at large. It can be a response to changes in the external environment or a preventive action that influences the environment in which it operates (West \& Anderson, 1996). This proves to be fundamental in the context of the socio-political and economic crisis in which the city finds itself, aiming to carry out interventions and preventive measures that revert this context. Rio de Janeiro also intends to position itself as a sustainable city, in other words, a city whose government pays attention to present needs and the bases for future generations, implementing programs to reduce the emission of polluting gases and depollution from rivers and lakes, as well as initiatives to seek energy efficiency, better water management, improved urban mobility, and urbanization of slums, for example. However, Rio de Janeiro still presents challenges such as gentrification and the reinforcement of socioeconomic asymmetries. The attraction of more people to this city in recent decades has been accompanied by rising prices, greater competition for jobs, and real estate speculation. This dynamic reverberates in the lack of incentives and subsidies for employment and decent housing conditions for the local population, which directly affects the environment, with the irregular occupation of land in slums and poor communities. Rio de Janeiro is vulnerable to climate change, which is seen in floods, heat waves, and impacts on infrastructure, such as landslides and damage to the drainage network, roads and the network of electricity, gas, telephone, and internet. In the post-Olympic context, the crisis in the real estate sector is also visible, with a large oversupply of residential and commercial properties, as well as in the hotel sector. Although Rio de Janeiro is endowed with countless natural beauties, most residents still see that its rivers and lakes only serve as waste deposits or mere contemplation scenarios. With the dumping of sewage into the waters and the multiplication of communities around lakes especially in the West Zone -, environmental degradation is advancing in the city. 
Environmental improvements promised with the realization of sporting megaevents in the city - such as the depollution of Guanabara Bay - never occurred (Freitas, 2013).

\section{Final considerations}

To strengthen the identity of Rio's brand, an analysis focused on the physical and symbolic dimensions was presented. The physical evidence of the brand is composed of attributes related to the productive, political and cultural-historical dimension of the city brand, while the symbolic evidence of it is formed by intangible attributes, connections with the place and the brand's potentialities. It is possible to state that, aiming to increasing the positive perception of Rio's brand, it would be essential to expand the political and social instruments for monitoring police actions and conduct cases of human rights abuses to national and international authorities responsible for these issues for investigation and possible punishment of those guilty of such abuses. This measure could be accompanied by encouraging the engagement of organized civil society groups in the formulation of municipal public policies and the monitoring of political actions and expenditures of municipal, state, and federal authorities, with a view to achieving greater public transparency. Greater articulation between national defense and public security policies is fundamental, particularly regarding the expansion of monitoring of the borders of the country and the state of Rio de Janeiro, with a view to curbing drug and arms trafficking and combat cargo theft. It is also worth mentioning the strengthening and acceleration of the political discussion about federal, state and municipal projects that generate income and employment for populations with lower income and below the poverty line, particularly in sectors linked to the vocations of the city. In addition, it would be essential for public authorities to engage with the business sector and the third sector in the training of citizens for the insertion of such people in productive sectors related to urban vocations, with the use of local knowledge in the generation of income and employment. In terms of stimulating social cohesion, it would be important to expand institutional cooperation among the different levels of government, the private sector and organized sectors of civil society in the holding of events and encourage the diversity of artistic and cultural manifestations in the realization of these events, which allow the creation and consolidation of connections between people and the city and explore its potential for the development of individual freedom (Jesus, 2019).

As can be seen in the literature on the subject, influences and dynamic processes among the components of the brand identity encompass the way a place brand is perceived (Jacobsen, 
2012; Mariutti, 2019), as they also influence the experience branding (Mariutti, 2019). These themes relate to the strategies of cities and nations, in terms of urban planning and regional development. In this sense, given the actual competitiveness among cities, regions and countries, the dimensions here considered provide another way to understand issues related to social, economic and sustainable attributes.

This study is limited by its scale, since the focus is only in Rio de Janeiro city, and because the method is a qualitative one. Future research could consider using quantitative methods in order to obtain generalizable findings. Also, the study of place brands through scales different from those of cities could be performed, to better understand the identity, image and reputation at other dimensioning levels of the creative territory.

\section{References}

Aitken, R., \& Campelo, A. (2011). The four R's of place branding. Journal of Marketing Management, 27(9-10), 913-933.

Barreira, G. (2021). Tribunal que julga impeachment de Witzel ouve testemunhas nesta quarta-feira. Retrieved from https://g1.globo.com/rj/rio-dejaneiro/noticia/2021/01/13/tribunal-que-julga-impeachment-de-witzel-ouve-testemunhasnesta-quarta-feira.ghtml. Access: June 19th, 2021.

Berrone, P. \& Ricart, J. E. (2016). IESE cities in motion index 2016. Navarra: Iese Business School, University of Navarra.

Betim, F. (2020). Flávio Bolsonaro é denunciado por lavagem de dinheiro e organização criminosa no caso da 'rachadinha'. Retrieved from https://brasil.elpais.com/brasil/202011-04/flavio-bolsonaro-e-denunciado-por-lavagem-dinheiro-e-organizacao-criminosa-nocaso-da-rachadinha.html. Access: June 19th, 2021.

Bowen, G. (2009). Document analysis as a qualitative research method. Qualitative Research Journal, 9 (2), 27-40. https://doi.org/10.3316/QRJ0902027

Braun, E. (2008). City Marketing: Towards an Integrated Approach. ERIM PhD Series in Research and Management, 142, Erasmus Research Institute of Management (ERIM), Rotterdam, Retrieved May 7, 2021 from http://hdl.handle.net/1765/13694

Braun, E. \& Zenker, S. (2010). Towards an Integrated Approach for Place Brand Management, 50th Congress of the European Regional Science Association: "Sustainable Regional Growth and Development in the Creative Knowledge Economy", 19-23 August 2010, Jönköping, Sweden, European Regional Science Association (ERSA), LouvainlaNeuve. 
Caldwell, N. \& Freire, J. R. (2004). The differences between branding a country, a region and a city: Applying the Brand Box Model. Journal of Brand Management, 12 (1), 50-61.

Cheverton, P. (2012). Understanding Brands. Glasgow: Kogan Page.

Coelho, H. \& Rodrigues, M. (2017). Governos e empresários anunciam calendário de grandes eventos para a cidade. Retrieved from https://g1.globo.com/rio-dejaneiro/noticia/prefeitura-do-rio-anuncia-calendario-de-grandes-eventos-para-acidade.ghtml. Access: June 23rd, 2021.

Delgado-García, J.B., de Quevedo-Puente, E., \& Blanco-Mazagatos, V. (2017). The impact of city reputation on city performance. Regional Studies, 52, 1098-1110. https://doi.org/10.1080/00343404.2017.1364358

Diário do Rio (2021). Centro do Rio passa por crise sem precedentes. Retrieved from https://diariodorio.com/centro-do-rio-passa-por-crise-sem-precedentes/ . Access: June 19th, 2021.

Exame (2020). Carnaval de rua do Rio de 2021 é cancelado; blocos vão aguardar a vacina. Retrieved from https://exame.com/brasil/carnaval-de-rua-do-rio-de-2021-e-canceladoblocos-vao-aguardar-a-vacina/ . Access: June 19th, 2021.

Firjan (2021). Índice De Confiança Do Empresário Industrial Fluminense - Icei-Rj. Retrieved from https://www.firjan.com.br/publicacoes/publicacoes-de-economia/indice-deconfianca-do-empresario-industrial-fluminense-2.htm. Access: May 1st, 2021.

Franzen, G. \& Bouwman, M. (2001). The Mental World of Brands. Henley-on-Thames: Warc.

Freitas, C. (2013). Rio de Janeiro: cidade modelo de sustentabilidade? Retrieved from http://www.jb.com.br/rio/noticias/2013/12/01/rio-de-janeiro-cidade-modelo-desustentabilidade/. Access: June 23rd, 2021.

Gammelsæter, H. (2017). Media visibility and place reputation: does sport make a difference? Journal of Place Management and Development, 10 (3), 288-298. https://doi.org/10.1108/JPMD-01-2017-0004

G1 (2020). Entenda a investigação que levou Crivella à prisão. Retrieved from https://g1.globo.com/rj/rio-de-janeiro/noticia/2020/12/22/entenda-o-esquema-que-levou-aprisao-de-crivella.ghtml. Access: June 19th, 2021.

Grinberg, F. (2020) Covid-19: Fiocruz alerta que Saúde do Rio já está em colapso com novo avanço de casos. Retrieved from https://oglobo.globo.com/rio/covid-19-fiocruz-alerta-quesaude-do-rio-ja-esta-em-colapso-com-novo-avanco-de-casos-1-24777705. Access: June, 19th, 2021.

Hanna, S., Rowley, J., \& Keegan, B. (2021). Place and Destination Branding: A Review and Conceptual Mapping of the Domain. European Management Review, 18, 105-117, (202 
Jesus, D. S. V. (2017). Saudade de mim: patrimônio cultural e economia criativa no Rio de Janeiro. In: J. L. Figueiredo \& D. S. V. Jesus (Org.). Cidades Criativas: Aspectos Setoriais $e$ Territoriais, 157-177. Rio de Janeiro: E-Papers.

Jesus, D. S. V. (2019). O Decreto No. 9.288 e a intervenção federal no Estado do Rio de Janeiro: motivações e repercussões político-sociais e econômicas. Revista de Direito da Cidade, 11(2), 194-214. https://doi.org/10.12957/rdc.2019.37571

Jesus, D. S. V. (2020). Necropolitics and Necrocapitalism: The Impact of COVID-19 on Brazilian Creative Economy. Modern Economy, 11 (6), 1121-1140. https://doi.org/10.4236/me.2020.116082

Jesus, D. S. V. (2021). As If There Were No Tomorrow: New Year's CovidFests in Brazil. Sociology Study, 11(1), 33-36. https://doi.org/10.17265/2159-5526/2021.01.003

Jesus, D. S. V., Kamlot, D., \& Dubeux, V. J. C. (2020). Innovation in the 'New Normal? Interactions, the Urban Space, and the Low Touch Economy: The Case of Rio de Janeiro in the Context of the COVID-19 pandemic. International Journal Of Social Science Studies, 8 (5), 17-27. https://doi.org/10.11114/ijsss.v8i5.4900

Jesus, D. S. V., Kamlot, D., Dubeux, V. J. C., Reis, P. C., \& Robaina, D. T. (2019). "Olha que coisa mais linda, mais cheia de graça": a violência física e simbólica contra a mulher na Marca Rio (2016-2018). Caderno Espaço Feminino, 32(2), 250-279. https://doi.org/10.14393/CEF-v32n2-2019-13

Jones, J. (2004). A publicidade na construção de grandes marcas. São Paulo. Nobel.

Kamlot, D. (2012). Interferência do Estado na sociedade: uma visão de marketing social. Revista da ESPM, 19 (3), 78-83.

Kamlot, D. (2017). Resiliência organizacional e marketing social: uma avaliação de fundamentos e afinidades. Cadernos EBAPE. BR. 15(n. spe), 482-495. https://doi.org/10.1590/1679-395160269

Kamlot, D. \& Fajardo, B. G. (2019). Marketing. Rio de Janeiro: FGV.

Kamlot, D. \& Jesus, D. S. V. (2020). Uncertainty during Covid-19 Outbreak in Brazil: Clashes between the President and Governors. International Journal of Humanities and Social Science, 10 (6), 36-41. https://doi.org/10.30845/ijhss.v10n6p5

Kapfereer, J-N. (2008). Strategic Brand Management: Creating and Sustaining Brand Equity Long Term. London: Kogan Page.

Kotler, P. Marketing essencial. (2012). São Paulo: Prentice Hall

Kotler, P. \& Gertner, D. (2002). Country as a brand, product, and beyond: A place marketing and brand management perspective. Journal of Brand Management, 9 (4-5), 249-261. https://doi.org/10.1057/palgrave.bm.2540076 
Mariutti, F. G. (2019). Fundamentos teóricos sobre marketing de lugar, gestão de marca de lugar e valor de marca de lugar. Comunicação \& Mercado, 6 (14), 163-184.

Mariutti, F.G. \& Giraldi, J.M.E. (2021). Branding cities, regions and countries: the roadmap of place brand equity. RAUSP Manag. J., 56 (2), 202-216,

Moura, L. (2021). O que esperar do desemprego no Estado do Rio em 2021? Retrieved from https://odia.ig.com.br/economia/2021/01/6060648-o-que-esperar-do-desemprego-noestado-do-rio-em-2021.html. Access: June 19 ${ }^{\text {th }}, 2021$.

Nunes, G. \& Haigh, D. (2003). Marca: valor do intangível. São Paulo: Atlas.

Ocke, M. A. M. \& Ikeda, A. A. (2014). Marketing de lugar: estado da arte e perspectivas futuras $R$. Adm., 49 (4), 671-683. https://doi.org/10.5700/rausp1176

Reis, P. C. (2018). A Marca da Cidade: Reflexões e Proposições para Construção e Gestão de Marcas de Cidades. O Caso do Rio de Janeiro. Curitiba: Appris.

Reputation Institute. (2014). 2014 City rep trak: the world's most reputable cities. Retrieved from https://www.internations.org/magazine/the-world-s-most-reputable-cities-18848 Access July $13^{\text {th }}, 2021$.

Ries, A. \& Ries, L. (2009). The 22 immutable laws of branding: how to build a product or service into a world-class brand. New York: HarperCollins Publishers.

Ritchie, J. R. B. \& Ritchie, R. J. B. (1998). The Branding of Tourism Destinations: Past Achievements and Future Challenges. Proceedings of the 1998 Annual Congress of the International Association of Scientific Experts in Tourism, Destination Marketing: Scopes and Limitations, edited by Peter Keller. Marrakech: International Association of Scientific Experts in Tourism, 89-116.

Saffron B. C. (2013) The Saffron European City Brand Barometer: revealing wich cities get the brands they deserve. Jeremy Hildreth. London: Saffron Brand Consultants

Sampaio, R. (2013). Propaganda de A a Z. 3.ed. Rio de Janeiro. Campus.

Sampaio, R. (2006). Ranking da Interbrand destaca Coca-Cola e Google. Retrived May 10, 2020, from www.portaldapropaganda.com/marketing/2006/07/0002,

Sanny, L. et al. (2020). Purchase intention on Indonesia male's skin care by social media marketing effect towards brand image and brand trust. Management Science Letters, 10, 2139-2146.

Schiffman, L.G. \& Kanuk, L.L. (2009). Consumer Behavior. London: Prentice Hall.

SECEC-RJ. (n.d.). Aldir Blanc - Editais. Retrieved from http://cultura.rj.gov.br/lei-aldirblanc-editais/. Access: June 19th, 2021.

Severino, A. J. (2018). Metodologia do trabalho científico. São Paulo: Cortez. 
Skinner, H. (2011). In search of the genius IOCI: The essence of a place brand. The Marketing Review, 11 (3). 281-292.

Teleport (2020). Quality of life in Rio de Janeiro. 2020. Retrieved from https://teleport.org/cities/rio-de-janeiro/ Access: February 23rd, 2021.

Tybout, A.M. \& Carpenter, G.S. (2013). Criação e gestão de marcas. In: Calder, B.J. \& Tybout, A.M. (Orgs.). Marketing. São Paulo: Saraiva, 119-153.

Van den Berg, L. \& Braun, E. (1999). Urban competitiveness, marketing and the need for organising capacity. Urban Studies, 36 (5-6), 987-999.

https://doi.org/10.1080/0042098993312

Veja Rio (2016). Pesquisa revela que $71 \%$ dos cariocas estão insatisfeitos com a cidade. Retrieved from https://vejario.abril.com.br/cidades/pesquisa-revela-que-71-dos-cariocasesta-insatisfeito-com-a-cidade/. Access: June 23rd, 2021.

West, M. A. \& Anderson, N. (1996). Innovation in Top Management Teams. Journal of Applied Psychology, 81 (6), 680-693. https://doi.org/10.1037/00219010816680

Zenker, S. (2011). How to catch a city? The concept and measurement of place brands. Journal of Place Management and Development, 4(1), 40-52. https://doi.org/10.1108/17538331111117151 
Recebido: 26 jun. 2021/Aprovado: 12 jan. 2022

Editores responsáveis: Julio Araujo Carneiro da Cunha \& André Torres Urdan

Editores Convidados: Fabiana Mariutti \& Magdalena Florek Processo de Avaliação: Double Blind Review e-ISSN: $2177-5184$

https: / / doi.org/10.5585/remark.v21i1.20344

\title{
IDENTIDADE DA MARCA RIO DE JANEIRO: UMA ANÁLISE DAS DIMENSÕES FÍSICA E SIMBÓLICA
}

\author{
Daniel Kamlot \\ ESPM; FGV-Ebape; PUC-Rio. \\ Rio de Janeiro, RJ - Brazil. \\ danielkamlot@yahoo.com.br \\ Diego Santos Vieira de Jesus \\ PUC-Rio. \\ Rio de Janeiro, RJ - Brazil. \\ dsvj@puc-rio.br
}

Objetivo: Apresentar uma análise da identidade da marca Rio em suas dimensões física e simbólica, seguindo a teoria segundo a qual a marca de uma cidade é composta por três elementos distintos: identidade, imagem e reputação, sendo a identidade da marca erigida a partir de evidências físicas e simbólicas.

Metodologia: Foi utilizado um método qualitativo de análise documental, o qual requer que os dados dos documentos sejam revisadose interpretados para extrair significado e compreensão, seguindo algumas etapas: pesquisa bibliográfica; análise temática; coleta e avaliação de dados; identificação de dados significativos; interpretação de dados; análise de informações; e discussão dos achados. Foram acessados aproximadamente 284 documentos, entre pesquisas, e-mails, boletins, relatórios empresariais e governamentais, artigos de jornais etc.

Principais resultados: Os resultados expõem as diferenças e peculiaridades das dimensões física e simbólica da identidade da marca Rio. Enquanto na dimensão física a marca Rio teve um fraco desempenho no aspecto produtivo, no âmbito histórico-cultural o governo municipal tem buscado ampliar a rede de espaços públicos culturais, fortalecendo o acesso à cultura. No aspecto político, notou-se a dificuldade de criar espaços de participação da sociedade civil na formulação de políticas públicas. Em relação à dimensão simbólica, atributos intangíveis têm apontado recentemente níveis insatisfatórios de estima, admiração e confiança dos cariocas por uma marca de cidade de sucesso, com importantes iniciativas de promoção das conexões e potencialidades da cidade fortemente baseadas em inovação e sustentabilidade. Juntas, essas dimensões podem fortalecer a identidade da marca do Rio, indicando instrumentos adequados para o desenvolvimento da cidade.

Contribuições teóricas e metodológicas: As principais contribuições deste estudo são realizar a exploração das dimensões física e simbólica da identidade da marca de uma cidade e interpretá-la em detalhes, considerando a evolução recente da cidade. Contribui também para a literatura de marketing, abordando elementos da marca da cidade raramente discutidos teoricamente, como as dimensões física e simbólica da identidade da marca da cidade e seus componentes.

Relevância e Originalidade: $\mathrm{O}$ estudo das dimensões física e simbólica da identidade da marca de uma cidade é muito raro na literatura de marketing, por isso esta investigação oferece uma nova forma de compreender a conjuntura de uma cidade - por meio de suas dimensões produtiva, política e histórico-cultural, e também considerando suas conexões, potencialidades e atributos intangíveis -, que pode auxiliar em futuros estudos relacionados à interpretação da identidade da marca do lugar e desse campo de conhecimento.

Implicações gerenciais e sociais: Este estudo fornece apreciações e conhecimentos que facilitam o projeto de políticas públicas a partir da compreensão da identidade atual da cidade.

Palavras-chave: Rio de Janeiro. Identidade de marca. Dimensão física. Dimensão simbólica. Marca de lugar.

\section{Como citar}

American Psychological Association (APA)

Kamlot, Daniel., \& Jesus, D. S. V. (2022, jan./mar.). Identidade da marca Rio de Janeiro: uma análise das dimensões física e simbólica. Revista Brasileira de Marketing - ReMarK, 21(Num. Esp.), 66-90.

https://doi.org/10.5585/remark.v21i1.20344. 


\section{Introdução}

Para conceber uma marca, é necessário entender a mente do consumidor a fim de garantir que as características próprias do produto não se limitem apenas aos seus conceitos meramente funcionais (Nunes \& Haigh, 2003). Ao criar a personalidade de uma marca e sua relação com o consumidor, surge um significado para o produto de forma que se estimule o desejo no consumidor e se crie uma percepção positiva para a imagem do que é oferecido. A marca evoluiria, assim, da funcionalidade para a fidelização, passando pela valorização.

Segundo Ries e Ries (2009), uma marca se torna tão poderosa quanto sua capacidade de influenciar o comportamento de compra. Assim, as empresas não vendem doces, copos ou motocicletas; elas vendem sentimentos e sensações, e elevam a identificação. O conceito de marca, então, é realmente importante para uma empresa. Como qualquer bem patrimonial, também deve ser submetido a constantes procedimentos de manutenção e até rejuvenescimento.

O desempenho de uma marca também está diretamente ligado à forma como esta atende às necessidades psicológicas e sociais do consumidor (Kamlot, 2013; 2017), que são responsáveis por conduzir a decisão de compra, pelo menos em parte. A partir daí a marca pode fornecer um significado para o cliente, que formará em sua mente a imagem da marca, causando - ou não - reconhecimento e valorização dela, não apenas no aspecto financeiro, mas no "conjunto de benefícios econômicos, funcionais e psicológicos que os consumidores esperam de uma determinada oferta" (Kotler, 2012, p. 40).

Conforme explicado por Cheverton (2012), uma das maiores potencialidades de uma marca valiosa é que ela exerce todo o seu poder na mente dos consumidores, o que parece estar alinhado com a percepção da imagem da marca. Muitas vezes se estabelece uma conexão emocional entre marca e consumidor. De acordo com a percepção do consumidor sobre a marca, ocorre uma relação entre ambos, contribuindo de forma positiva ou negativa, dependendo de aquele gostar ou não da imagem de marca formada, o que será decisivo em termos de lealdade e fidelidade.

Franzen e Bouwman (2001) percebem as marcas como entidades vivas em um mundo mental, como um conjunto de elementos de memória, agrupados e moldados por certos "esquemas". Nesse mundo mental das marcas, os itens de memória da marca geralmente são obtidos inconscientemente; por sua vez, as decisões relacionadas à marca não são totalmente conscientes. 
Atualmente, as marcas são percebidas como uma ferramenta importante não só para empreendedores e negócios em geral, mas também para lugares. Apesar de sua intangibilidade, uma marca pode ser entendida como um importante ativo estratégico, responsável pela diferenciação, que motiva o consumidor a ter (mais) interesse por algum produto ou serviço que lhe é oferecido (Kotler \& Gertner, 2002), e o mesmo é percebido em relação às marcas de lugar.

Considerando o "acordo geral entre acadêmicos e profissionais de que os lugares podem ser marcados da mesma forma que bens de consumo e serviços" (Caldwell \& Freire, 2004, p.5051), este artigo focará na identidade da marca relacionada à cidade do Rio de Janeiro, uma das mais famosas e relevantes cidades brasileiras. O objetivo é apresentar uma análise da identidade da marca carioca em suas dimensões física e simbólica, seguindo a teoria definida por Reis (2018) - segundo a qual a marca da cidade é composta por três elementos distintos: identidade, imagem e reputação, sendo a identidade da marca edificada a partir de evidências físicas e simbólicas.

A principal contribuição deste artigo está relacionada a uma compreensão mais ampla das conexões entre as diferentes dimensões da marca da cidade e seu potencial para definir políticas públicas adequadas, considerando a avaliação dos aspectos físicos e simbólicos inerentes à cidade. Mais especificamente, as dimensões que englobam evidências físicas e simbólicas auxiliam na definição dos vínculos entre a cidade e seus habitantes, a fim de auxiliar os gestores a explorar o potencial da cidade para o desenvolvimento de questões de infraestrutura, meio ambiente, engajamento e planejamento social.

\section{Referencial teórico}

\section{Marcas e sua importância}

A literatura sobre marcas geralmente é focada em empresas e corporações de diferentes setores, localidades e tamanhos. Embora as marcas possam criar valor e consolidar a confiança na empresa, ajudando a aumentar seus lucros (Kapferer, 2008), não é possível supor que isso seja verdade para todas as áreas de atuação.

A importância das marcas é crescente, tanto para os fabricantes quanto para os consumidores que pretendem adquirir um produto. $\mathrm{O}$ valor de certas marcas já representa a maior parte do valor de mercado de várias empresas (Sampaio, 2006), indicando a crescente relevância desse ativo intangível para os negócios em geral. Além disso, uma marca forte pode 
ser responsável por uma enorme contribuição para um lugar, como uma cidade, uma nação ou um local específico (Hanna et al., 2021), e possuir benefícios dimensionais que facilitam a compreensão do que os cidadãos valorizam em uma marca de lugar (Mariutti \& Giraldi, 2021).

É interessante notar que as marcas foram desenvolvidas para uma série de propósitos diferentes. O inicial era conferir proteção legal sob a patente do inventor; o segundo era garantir qualidade e homogeneidade após a diminuição do contato pessoal entre comprador e vendedor em função do crescimento da industrialização. O terceiro propósito decorre da necessidade das corporações distinguirem seus produtos. Até hoje, os fabricantes fazem todo o possível para diferenciar suas marcas a fim de levar os consumidores a acreditar que são únicos, pois uma marca forte reduz a probabilidade de substituição (Jones, 2004).

As mudanças no mercado aumentaram o poder das marcas. A partir do momento em que uma marca agrega valor ao produto, ela ganha maior relevância, pois possui um relacionamento prévio com o consumidor, incluindo as experiências positivas obtidas com aquele produto (Sampaio, 2013). Isso é observado não apenas para produtos, mas também para ideias, comportamentos, serviços e lugares (Kamlot \& Fajardo, 2019). Considerando que uma imagem de marca se relaciona com as percepções do consumidor em relação a uma marca promovida pela interação dos processos afetivos, cognitivos e avaliativos na mente de um cliente (Lee et al., 2019), é possível perceber que quando um cliente confia em uma marca, a importância desta cresce, levando ao comprometimento e afeição para com essa mesma marca (Sanny et al., 2020).

\section{Brand perception and place brands}

A percepção pode ser compreendida pela forma como os indivíduos veem o mundo ao seu redor (Schiffman \& Kanuk, 2009). Duas pessoas podem ser submetidas aos mesmos estímulos sob as mesmas condições aparentes, mas a forma como cada uma reconhece e interpreta cada estímulo ou fenômeno é um processo individualizado, baseado nas necessidades, valores e expectativas de cada pessoa.

Uma marca se torna tão poderosa quanto sua capacidade de influenciar o comportamento de compra (Ries \& Ries, 2009). Daí a importância de perceber que uma marca, seu nome ou símbolo em uma embalagem, por exemplo, não pode ser avaliado da mesma forma que um nome de marca na mente do consumidor potencial. Para que uma marca ganhe 
relevância e sobreviva no mercado competitivo atual, é recomendável que se detenha um amplo conhecimento das necessidades e desejos emocionais das pessoas.

Consequentemente, o maior desafio é justamente definir uma marca por meio de um conjunto de significados para esta, e não apenas seu nome e símbolo, pois, assim, as chances de envolvimento com ela serão muito maiores, o que decorre do surgimento de oportunidades para perceber as vantagens e benefícios que tal marca pode oferecer - o chamado valor da marca (Tybout \& Carpenter, 2013)

Além disso, tendo em vista que as marcas têm propósitos diferentes para contextos diferentes, é preciso definir critérios e planejamentos específicos para cada situação. No caso dos lugares, a marca tem sido cada vez mais relevante, e desenvolver alguma marca de lugar (o chamado place branding) é mais difícil quando comparado com produtos ou serviços (Ocke \& Ikeda, 2014), portanto o conceito de percepção de marca de lugar (Figura 1) é relevante para qualquer planejamento. Segundo Braun e Zenker (2010, p.5), para entender o que é a percepção de marca de lugar é essencial perceber que uma marca "não é na realidade a expressão comunicada ou a 'física do lugar', mas a percepção dessas expressões na mente do(s) grupo(s)alvo". Os autores também enfatizam que "essas percepções levam a efeitos de marca como identificação, satisfação ou outros efeitos como viés de busca de informações, comprometimento e intenção de ficar", conforme mostrado na Figura 1.

\section{Figura 1}

\section{Conceito de Percepção de Marca de Lugar}

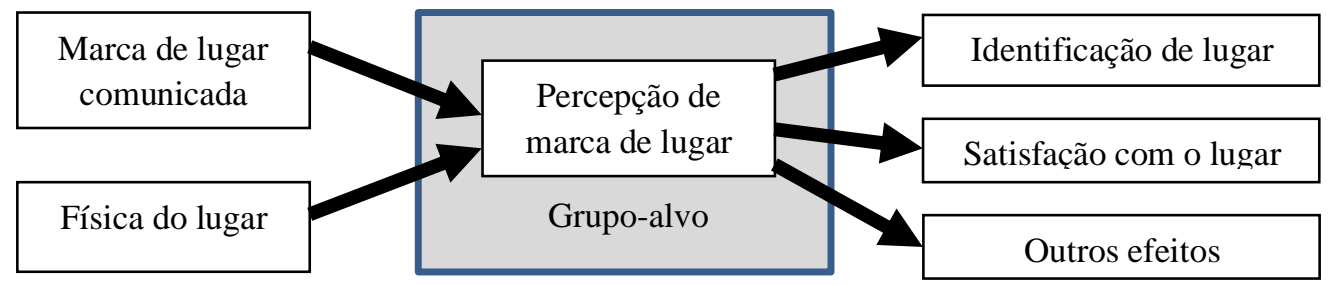

Fonte: Braun \& Zenker, 2010

Jacobsen (2012) estabeleceu um modelo conceitual que compreende agentes da marca do lugar relacionados ao comportamento do consumidor do lugar, como mostrado na Figura 2. $\mathrm{O}$ autor explica que alguns atributos da marca estão associados a oportunidades de gestão operacional da marca. Em relação às dimensões mencionadas por Jacobsen (2012), a dimensão tangível dos atributos da marca do lugar compreende qualidade, sentimento e promoção, e a 
dimensão intangível abrange consciência, patrimônio, imagem, personalidade, reputação e confiança.

\section{Figura 2}

Percepção e Comportamento
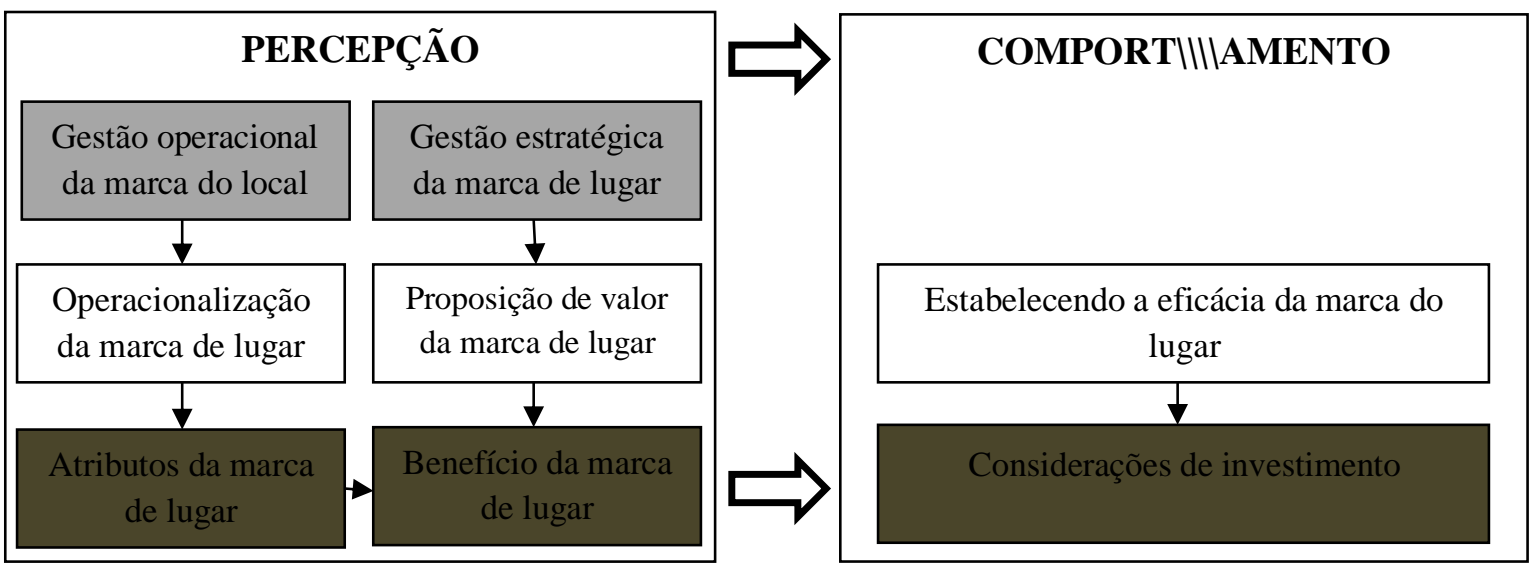

Fonte: Jacobsen, 2012.

Pode-se notar que a percepção da marca do lugar está relacionada a muitos atributos diferentes. Braun e Zenker (2010) mencionam que devido aos diferentes níveis de conhecimento dos consumidores e suas diferentes expectativas para um local, a percepção da marca varia significativamente entre os grupos-alvo. Assim, um conceito que auxilia a análise é o de identidade da marca de lugar, explicado a seguir.

\section{Identidade de marca de lugar}

Para entender o significado das marcas de lugar, é necessário investigar a literatura relacionada a esse assunto, que pode diferir entre os autores, especificamente no que se refere à definição do termo. Pesquisadores divergem muito sobre as definições a serem "aceitas" em relação à identidade do lugar e à marca do lugar, e às vezes há confusão entre marketing de lugar e marca de lugar, muitas vezes faltando um uso consistente dos termos (Zenker, 2011). O Quadro 1 apresenta as definições consideradas relevantes neste estudo. 


\section{Quadro 1}

Definições Relevantes: Marketing de Lugar, Marca de Lugar e Identidade de Marca

\begin{tabular}{|c|c|}
\hline Definições & Autor(es) \\
\hline $\begin{array}{l}\text { [Uma marca de lugar pode ser entendida como] um nome, símbolo, logotipo, marca } \\
\text { nominativa ou outro elemento gráfico que identifique e diferencie o destino; além disso, } \\
\text { transmite a promessa de uma experiência de viagem memorável, associada de forma } \\
\text { única ao destino; serve também para consolidar e reforçar a recordação de memórias } \\
\text { prazerosas da experiência do destino. }\end{array}$ & $\begin{array}{l}\text { Ritchie \& Ritchie } \\
\text { (1998, p.103) }\end{array}$ \\
\hline $\begin{array}{l}\text { [Marketing de lugar é definido como] o uso coordenado de ferramentas de marketing } \\
\text { apoiadas por uma filosofia compartilhada orientada para o cliente a fim de criar, } \\
\text { comunicar, entregar e trocar ofertas urbanas que tenham valor para os clientes da cidade } \\
\text { e para a comunidade da cidade em geral. }\end{array}$ & $\begin{array}{l}\text { Braun }(2008, p . \\
43)\end{array}$ \\
\hline $\begin{array}{l}\text { [Uma marca de lugar é definida como] uma rede de associações na mente dos } \\
\text { consumidores com base na expressão visual, verbal e comportamental de um lugar, que é } \\
\text { incorporada por meio dos objetivos, comunicação, valores e cultura geral dos } \\
\text { stakeholders do lugar. e do design geral do local }\end{array}$ & $\begin{array}{l}\text { Braun \& Zenker } \\
(2010, \text { p. 4) }\end{array}$ \\
\hline $\begin{array}{l}\text { A marca de lugar está ligada ao seu ecossistema (Bergvall, 2006), tanto humano quanto } \\
\text { natural, e depende das relações entre pessoas, comunidades, lugar e experiência. Essas } \\
\text { relações criam e revelam idiossincrasias e fundamentos culturais (Bergvall, 2006) que } \\
\text { determinariam a natureza da propriedade. Uma marca de lugar, por sua natureza, } \\
\text { pertence ao lugar e às suas pessoas. Essa relação genuína e fundacional, mesmo antes } \\
\text { das reivindicações conscientes da comunidade, influencia todos os aspectos da marca, } \\
\text { pois a criação de significados e valores constitui a base da propriedade }\end{array}$ & $\begin{array}{l}\text { Aitken \& } \\
\text { Campelo (2011, } \\
\text { p.917) }\end{array}$ \\
\hline $\begin{array}{l}\text { O marketing de lugar é analisado em termos de diferentes abordagens características de } \\
\text { sua natureza multidisciplinar. A maioria dos estudos procura conceituá-lo em referência } \\
\text { ao desenvolvimento sustentável do local, visando atender segmentos-alvo, identificados } \\
\text { como atuais e potenciais, com o intuito de criar, ou gerar, valor positivo para os } \\
\text { envolvidos, bem como fortalecer a atratividade e competitividade de um lugar com foco } \\
\text { nos mercados externo e interno. }\end{array}$ & $\begin{array}{l}\text { Ocke \& Ikeda } \\
(2014, \text { p.672) }\end{array}$ \\
\hline $\begin{array}{l}\text { A dimensão identidade da marca é dividida em evidência física e evidência simbólica da } \\
\text { marca. A evidência física da marca (...) é composta pelos elementos que compõem a } \\
\text { dimensão produtiva, política e histórico-cultural da marca. A evidência simbólica da } \\
\text { marca é formada pela identificação dos elementos que compõem os atributos intangíveis, } \\
\text { as conexões com o lugar e as potencialidades da marca. } \\
\text { As dimensões da identidade e imagem da marca são mediadas pela dimensão } \\
\text { comunicacional, que funciona como um fluxo de mão dupla entre a divulgação e } \\
\text { projeção dos elementos identitários da marca nos públicos e a incorporação e } \\
\text { reinterpretação da identidade da marca a partir das imagens que são formadas. nesses } \\
\text { mesmos públicos. }\end{array}$ & Reis (2018) \\
\hline $\begin{array}{l}\text { A marca de lugar representa uma rede de associações na mente dos públicos, baseada na } \\
\text { expressão visual, verbal e comportamental de um lugar, que engloba os propósitos, } \\
\text { comunicações, valores e cultura geral dos públicos envolvidos, bem como o espaço } \\
\text { urbano do lugar. }\end{array}$ & Mariutti (2019) \\
\hline
\end{tabular}

Fonte: Os autores.

Existem muitos modelos usados para analisar uma cidade. O Reputation Institute (2014), por exemplo, criou um modelo - chamado City RepTrak Pulse - que é focado em reputação, impactos econômicos e outras características, como o equilíbrio entre a realidade e a percepção que as pessoas têm do lugar. Nesse sentido, integram-se dois âmbitos de análise distintos: um emocional e outro racional. Saffron (2013) criou o Placemark Thermometer, para o qual foram definidos alguns fatores que delineiam a marca e influenciam a percepção das 
pessoas, sendo composto pelas características observáveis e mensuráveis da cidade para avaliar o quão forte a marca pode ser. E o Cities in Motion Index (Berrone \& Ricart, 2016), que apresenta uma abordagem de gestão de cidades baseada em quatro itens: ecossistemas sustentáveis, atividades inovadoras, igualdade entre cidadãos e conectividade territorial.

Considerando os atributos desses modelos, pode-se perceber que eles visam elaborar rankings e oferecer serviços de consultoria para melhorar a posição das cidades nesses mesmos rankings. Portanto, são direcionados não a muitas áreas distintas, mas a setores específicos de atividade, dificultando uma análise mais abrangente.

Por isso, este artigo estará concentrado no modelo e na definição de Reis (2018), em que a autora afirma que a marca da cidade é composta por três elementos distintos: identidade, imagem e reputação, sendo a identidade da marca construída a partir de elementos físicos e simbólicos, explicados a seguir. Este é um modelo mais abrangente, que pode auxiliar na presente pesquisa devido à sua adequação e pertinência.

\section{Evidências físicas}

As evidências físicas da identidade de uma marca são definidas por uma cadeia de elementos que caracterizam o local e materializam suas singularidades e diferenciais. Nesse aspecto, a marca não é apenas produtora de informações, mas promotora de relacionamentos. Para elaborar as evidências físicas, elementos relacionados à dimensão produtiva do território, à dimensão política e à dimensão histórico-cultural são incorporados à identidade, visto que “elementos políticos, históricos, sociais e culturais também contribuem para a essência de uma marca de lugar” (Skinner, 2011). A dimensão produtiva refere-se à articulação das indústrias e prestadores de serviços existentes no local, com suas vocações. Essa articulação proporciona melhor desenvolvimento tecnológico e econômico, economia estável e de baixo risco, além de ambientes mais favoráveis aos negócios. Fruto da articulação das diferentes indústrias e serviços existentes, a dimensão produtiva incorpora também a possibilidade de produtos e serviços locais de elevada qualidade, com marcas mais conhecidas. A dimensão política referese à existência de espaços de participação, à estrutura política do local e ao reconhecimento de uma gestão eficiente no local. Também se relaciona com a presença da cidade e de seus líderes e personalidades no cenário internacional. Esta dimensão considera a existência de espaços de participação social na formulação, implementação e fiscalização de políticas públicas e práticas de transparência pública, bem como a participação de lideranças locais em fóruns e instituições 
internacionais que visem à promoção da cidade na esfera externa. A dimensão históricocultural incorpora a preservação e recuperação de fatos e lugares históricos existentes, bem como referências culturais locais, o sentimento de pertencimento e a contribuição local para a cultura global. As instalações e os estabelecimentos de lazer e cultura representam esta dimensão e devem promover a singularidade do local. Esta dimensão engloba também eventos com visibilidade internacional realizados na cidade (REIS, 2018).

\section{Evidências simbólicas}

As evidências simbólicas são referentes à dimensão emocional que surge das experiências com o lugar e das expectativas existentes. Nesse aspecto, a marca é produtora de significados e promotora de emoções. Para elaborar a evidência simbólica, elementos relacionados aos atributos intangíveis, às conexões nele estabelecidas e ao potencial do lugar são incorporados à identidade da marca. Atributos intangíveis referem-se às experiências das pessoas com evidências físicas. Eles podem estimular associações positivas com a cidade e as relações que surgem entre os públicos por meio da marca. A estima, a admiração e a confiança que as pessoas sentem no local estão incorporadas a esses atributos. As conexões, baseadas em experiências com o lugar, são uma dimensão da marca da cidade composta por espaços presenciais e virtuais que estimulam as interconexões entre as pessoas e o lugar. Eventos são estratégias com alto poder de gerar conexões. Aqui também se insere o reconhecimento do lugar na mídia internacional, proporcionando novas conexões. As potencialidades referem-se aos elementos da marca que ainda são expectativas e perspectivas para o futuro e às melhorias decorrentes dos elementos presentes nas evidências físicas, no que diz respeito a inovação, empreendedorismo e desenvolvimento sustentável (Reis, 2018).

Reis (2018) afirma que a imagem se refere à comunicação da marca da cidade, que é responsável por dar visibilidade, estabelecendo correlações entre os elementos que estão associados às evidências física e simbólica. A transição entre o domínio da identidade e o domínio da imagem da marca ocorre por meio de esforços comunicacionais deliberados e espontâneos, gerando percepções variadas na memória das pessoas. Diferentes tipos de comunicação compõem a dimensão comunicacional da marca da cidade a partir da natureza de suas mensagens, da diversidade e da complexidade que uma marca de cidade traz em sua comunicação para se tornar aderente tanto ao local quanto aos públicos que com ela se relacionam. São eles: comunicação de engajamento; comunicação de serviços públicos; 
comunicação de novos negócios; comunicação com visibilidade internacional; e comunicação de opinião pública.

Embora o procedimento de criação de reputação não seja perfeitamente especificado (Gammelsæter, 2017), Delgado-García et al. (2017, p.1099) a definem como "a agregação das percepções de um único stakeholder sobre a capacidade da cidade de atender às demandas e expectativas de muitos stakeholders da cidade”. Assim, é relevante notar que as cidades se reportam a diversos stakeholders cujas reivindicações são variadas, sendo entendidas como locais não apenas para morar, mas também para trabalhar e se divertir. A cidade ainda oferece muitos serviços, dependendo das necessidades dos habitantes. Também pode ser vista como um local para empresas e empreendedores localizarem, comercializarem e investirem. Além disso, a cidade oferece uma mistura de cultura, educação e entretenimento para os turistas (Van den Berg \& Braun, 1999). Reis (2018) indica que a reputação da cidade se refere à soma das várias percepções que diferentes stakeholders têm da marca durante um período mais longo, permitindo-lhes fazer um julgamento sobre como se dá a gestão. Nesse caso, a reputação da marca da cidade é um processo de construção de percepções de diferentes públicos de uma marca em relação às experiências com a cidade por um período maior de tempo.

\section{Metodologia}

Esta pesquisa foi estruturada de forma a seguir um arranjo lógico e reflexivo, enfatizando a interpretação dos conteúdos encontrados em diversas fontes (Severino, 2018). Após ter sido compreendido o contexto da cidade do Rio de Janeiro nos últimos 3 anos (de 2018 a março de 2021), foi utilizado o método qualitativo de Bowen (2009) para análise documental, que requer que os dados dos documentos sejam revisados e interpretados para se extraírem significado e compreensão, produzindo conhecimento empírico.

Assim, o procedimento metodológico seguiu as seguintes etapas: (1) pesquisa bibliográfica, (2) análise temática, (3) coleta e avaliação dos dados, (4) identificação dos dados significativos e definição das informações relevantes, (5) interpretação dos dados conforme análise documental, (6) análise das informações (relacionadas às dimensões físicas e simbólicas da Marca Rio) e (7) discussão dos resultados.

A amostra obtida é composta por documentos e textos relacionados à situação e evolução do Rio de Janeiro nos últimos três anos, gerados por entidades governamentais e instituições privadas e acadêmicas. Isso permitiu uma análise documental adequada para que 
se fornecesse acesso a informações relevantes e uma ampla gama de dados relacionados às dimensões físicas e simbólicas da marca da cidade, o que auxiliou na contextualização do estudo em seu campo (Bowen, 2009).

Acessamos aproximadamente 284 documentos de diversos tipos, como relatórios empresariais e governamentais, trabalhos de pesquisa, e-mails, boletins e outros. Os documentos foram obtidos por meio de contatos com instituições públicas, autarquias, bibliotecas, pesquisadores e acadêmicos. Os critérios de inclusão foram relativamente simples: o cerne do documento deveria estar relacionado a algumas das dimensões que compõem a identidade da marca Rio de Janeiro, que se divide em evidências físicas e simbólicas (conforme explicado no Quadro 1). Pudemos coletar centenas de informações diferentes, mas, após avaliação, menos de 300 delas foram consideradas adequadas para a pesquisa. Com base nisso, foi realizada a interpretação dos dados. Estimamos que metade dos documentos pesquisados eram acadêmicos, e a outra metade estava dividida entre governamentais e privados.

\section{Análise e discussão dos resultados}

Em relação às evidências físicas da identidade da marca, a análise documental mostra que os elementos que compõem a dimensão produtiva tiveram um desempenho fraco. Desde 2017, indústrias e prestadores de serviços da cidade estão fragilizados por causa de uma crise político-econômica, que criou um desincentivo para o fomento das vocações locais, como produtos associados à marca da cidade. Entre os fatores que refletem essa crise, vale destacar o agravamento do desemprego e o aumento generalizado dos preços dos produtos, em grande parte alimentados pelo maior nível de violência no estado do Rio de Janeiro, principalmente na capital. Com foco específico em questões relacionadas ao emprego, embora a indústria tenha levado a um desempenho positivo dos níveis de emprego no Brasil em 2017 em relação a 2016, o Rio de Janeiro foi a exceção nacional. Até setembro de 2017, houve redução de 4.769 empregos no estado, principalmente na capital. A análise do Cadastro Geral de Empregados e Desempregados indicou que o Rio de Janeiro foi o município do estado que mais fechou vagas formais em 2017. A crise do petróleo, o comprometimento das empreiteiras após a Operação Lava-Jato, o endividamento da Petrobras e a crise fiscal no estado do Rio de Janeiro explicam a situação alarmante, que levou ao fechamento de empregos e demonstrou uma crescente desarticulação das indústrias e prestadores de serviços com suas vocações naturais, o que impactou negativamente o desenvolvimento tecnológico e econômico, a estabilidade 
econômica e negócios existentes na cidade, bem como o nível de emprego. De acordo com a Secretaria Municipal da Fazenda, a queda no número de empregos na cidade teve impacto direto na arrecadação do ISS, o imposto municipal sobre serviços. A crise generalizada que se abateu sobre o emprego no estado do Rio de Janeiro reflete a maior instabilidade econômica e o maior risco associado aos negócios existentes, além de desestimular a geração de novos empreendimentos e a criação de vagas de emprego, inclusive nos setores relacionados às vocações da cidade (Jesus et al., 2019).

Desde o primeiro trimestre de 2020, a pandemia do novo coronavírus levou ao encerramento temporário e permanente de empresas, à redução das atividades das que sobreviveram por conta de medidas de distanciamento social, à limitação do número de pessoas nos estabelecimentos e ao aumento do número de desempregados e subempregados. $\mathrm{O}$ desemprego no contexto da pandemia bateu recorde no estado do Rio de Janeiro em setembro de 2020, com mais de 1,2 milhão de desempregados, cerca de 405 mil a mais do que o registrado em maio do mesmo ano. A economia da cidade e do estado do Rio de Janeiro poderia se recuperar após a vacinação contra a Covid-19, o que faria a curva de emprego voltar a crescer a partir do segundo semestre de 2021. No entanto, o primeiro semestre de 2021 ainda foi difícil, marcado pelo impacto do fim do Auxílio Emergencial, benefício instituído no Brasil pela Lei 13.982/2020, que previa o repasse de 600 reais por mês (inicialmente por três meses) para trabalhadores informais e de baixa renda, microempreendedores individuais e contribuintes individuais do Instituto Nacional do Seguro Social para minimizar os impactos econômicos causados pela pandemia. No início de setembro de 2020, o Governo Federal anunciou o pagamento de mais quatro parcelas de 300 reais até dezembro de 2020. A partir de 2021, esperava-se que as vendas caíssem ainda mais, o desemprego aumentasse por falta de consumidores, o dinheiro circulasse menos em economia, e o comércio tivesse que reduzir ainda mais seus custos (Moura, 2021). Além da volta do auxílio, especialistas defenderam a volta do programa de suspensão de contrato de trabalho e a redução da jornada de trabalho, o que teria evitado uma massa muito maior de desempregados. No caso específico da cidade do Rio de Janeiro, uma das áreas cuja atividade econômica foi mais afetada pela pandemia foi o Centro da cidade. Após o crescimento gradativo com o advento do Porto Maravilha, no início de 2021 a região apresentava muitos imóveis vazios, vários moradores de rua, falta de segurança pública, destruição do patrimônio histórico e insegurança para novos investimentos diante da grave crise econômica. Em janeiro de 2021, o prefeito Eduardo Paes lançou o plano Reviver Centro, que busca estimular a recuperação social, econômica e urbana do Centro da cidade, 
permitindo novos usos para estimular a construção de novas residências e a reconfiguração de prédios comerciais, transformando-os em edifícios residenciais ou mistos (Diário do Rio, 2021).

Na dimensão política da identidade da marca, alguns elementos dificultaram a criação de espaços de participação da sociedade civil na formulação de políticas públicas na cidade do Rio de Janeiro. A recessão econômica - aliada à retração das atividades da indústria do petróleo e à queda na arrecadação - levou à crescente pauperização da população, agravada ainda mais pela corrupção disseminada pelo aparato político do estado do Rio de Janeiro. Essa disseminação ficou evidente com a prisão dos ex-governadores Sérgio Cabral Filho, em 2016, e Luiz Fernando Pezão, em 2018, no contexto da Operação Lava Jato, bem como de exsecretários e conselheiros do Tribunal de Contas. A situação levou não só à escassez de recursos para o pagamento dos salários dos servidores do Estado, mas ao colapso gradual de programas do governo estadual, como as Unidades de Pronto Atendimento (UPAs) e as Unidades de Polícia Pacificadora (UPPs) ao longo de 2017. Ainda que grupos de cidadãos tenham se mobilizado politicamente diante de tal situação - inclusive por meio da realização de eventos públicos em toda a cidade, como fizeram servidores públicos dos setores de educação e saúde em 2017 -, tal engajamento teve pouco efeito político, pois esbarrou na permanência de coligações políticas nos poderes Executivo e Legislativo municipais, o que indicou a falta de recursos para pagamento de salários e novos investimentos na cidade. Além disso, a situação econômica e política desfavorável fez com que a criminalidade se espalhasse mais pela cidade, de modo que áreas de engajamento dos cidadãos, como associações comunitárias, tiveram seu acesso bloqueado na disputa entre policiais e criminosos. Embora as bases das UPPs permaneçam nos locais onde foram instaladas, esses locais vêm sendo gradualmente reocupados por facções criminosas desde o final dos Jogos Olímpicos de 2016. Diante da falta de uma política específica de segurança pública, o governo do estado do Rio de Janeiro voltou a focar no combate às drogas ao longo de 2017 , que vitimizaram principalmente a população negra e de baixa renda. Os ataques aos narcotraficantes recuperaram um cenário de interrupção do ensino público e privado e dos serviços comerciais nas regiões dominadas pelas facções. A situação de violência generalizada dificultou a mobilização nas comunidades afetadas pela guerra entre forças estatais e facções criminosas. No primeiro trimestre de 2018, uma série de episódios de violência durante o Carnaval - principalmente na cidade do Rio de Janeiro e a maioria deles contra as mulheres - influenciou a decisão do Governo Federal de realizar uma intervenção no estado do Rio de Janeiro. Essa decisão trouxe uma mudança na estrutura política 
que trata do tema da segurança pública, o que impacta diretamente na dimensão política da identidade da marca da cidade do Rio de Janeiro. Isso se traduziu em uma tentativa oficial de restaurar a estabilidade da ordem pública na cidade e no resto do estado. O cerceamento das práticas de participação social na formulação de políticas públicas na cidade do Rio de Janeiro ficou evidente com os assassinatos da vereadora do PSOL Marielle Franco e seu motorista Anderson Gomes em março de 2018. Franco era uma defensora dos direitos das mulheres, da população LGBT+, dos negros e da população das comunidades mais pobres da cidade. Na Câmara Municipal, ela fez parte de uma comissão cujo objetivo era monitorar a intervenção federal no Rio de Janeiro e foi escolhida como relatora em fevereiro de 2018. Franco criticou a intervenção federal, os abusos policiais e as violações de direitos humanos. A imprensa nacional e a internacional destacaram a morte de Franco como um ataque direcionado, criticando a violência policial na cidade e no estado do Rio de Janeiro (Jesus, 2019).

A crise na dimensão política das evidências físicas da identidade da Marca Rio tornouse ainda mais alarmante pelo agravamento da precariedade da estrutura política local e pelo reconhecimento, por grande parte da população, da ineficiência da gestão do então prefeito Marcelo Crivella. Após buscar acordos para manter seu cargo diante das tentativas de impeachment, Crivella não reduziu significativamente gastos desnecessários com cargos comissionados e criação de subsecretários. Ele acabou na prisão em dezembro de 2020, poucos dias antes de deixar o cargo. A prisão foi resultado de uma ação que apurou um esquema de corrupção na administração municipal e revelou a existência de um "quartel-general de propina" na Prefeitura. A operação conjunta do Ministério Público do Rio de Janeiro com a Polícia Civil apontou que empresários pagavam para ter acesso a contratos e receber valores devidos pela gestão municipal (G1, 2020).

A pandemia de Covid-19 evidenciou a fragilidade na gestão do sistema público de saúde. Em dezembro de 2020, a rede pública da cidade do Rio de Janeiro já estava em colapso, com centenas de pessoas aguardando um leito de UTI na região metropolitana. Na rede privada, a situação também era preocupante, pois quase todos os leitos de terapia intensiva da cidade estavam ocupados. Os hospitais sofreram não apenas com a superlotação, mas também com a falta de cuidados básicos. O aumento de óbitos fora dos hospitais em meados de outubro de 2020 foi um indicativo de que houve falta de atendimento à saúde dos cariocas devido, em grande parte, à desmobilização de leitos após os meses com maior número de casos e óbitos de Covid-19 no município. Além das mortes causadas diretamente pelo novo coronavírus, especialistas da Fiocruz destacaram que muitas outras ocorreram por doenças crônicas, como 
diabetes e hipertensão, causadas indiretamente pela pandemia devido à restrição de acesso a saúde. Uma das preocupações da Fiocruz era a de que o aumento de casos da doença acontecesse próximo às comemorações de final de ano e alertava que a falta de atendimento poderia se agravar se não houvesse reforço na estrutura hospitalar (Grinberg, 2020). O embate entre as diretrizes da Presidência da República e do Ministério da Saúde e de governos locais como prefeituras enviou sinais contraditórios à população brasileira durante a pandemia do novo coronavírus. Muitos debates surgiram nas redes sociais sobre a necessidade de manter as medidas de distanciamento social ou retornar às atividades econômicas normais. Com a intensificação da pandemia e a extensão das medidas restritivas, grande parte da população passou a desconsiderar as medidas sanitárias e, com a abertura prematura do comércio em várias regiões de cidades como o Rio de Janeiro, geraram-se aglomerações, principalmente em bares, restaurantes e boates (Jesus, 2021).

Alguns eventos envolvendo lideranças políticas da cidade e do estado do Rio de Janeiro dificultaram a articulação mais intensa entre a esfera local e as demais esferas de governo, como no processo de impeachment do governador Wilson Witzel. Witzel foi destituído do cargo em agosto de 2020, suspeito de corrupção. O esquema criminoso foi descoberto devido a irregularidades na contratação de hospitais de campanha, respiradores e medicamentos para combater a pandemia do novo coronavírus. A Procuradoria Geral da República afirmou que o governo do estado do Rio de Janeiro havia estabelecido um esquema de propina para contratação emergencial e liberação de pagamentos a organizações sociais que prestavam serviços ao governo (Barreira, 2021). Vale lembrar também os desdobramentos relacionados ao esquema da "rachadinha" no gabinete de Flávio Bolsonaro na Assembleia Legislativa, em que assessores parlamentares devolviam parte de seu salário aos políticos que os empregavam. Em novembro de 2020, o senador Bolsonaro foi denunciado pelos crimes de peculato, lavagem de dinheiro, organização criminosa e apropriação indébita pelo Ministério Público do Rio de Janeiro. O ex-policial militar e ex-assessor Fabricio Queiroz - uma espécie de faz-tudo da família Bolsonaro e considerado o operador financeiro do grupo - e outros 15 ex-assessores também foram formalmente acusados pelo Ministério Público. Bolsonaro foi acusado de desviar parte do salário de conselheiros fantasmas (Betim, 2020).

Na dimensão histórico-cultural, o governo municipal buscou até 2016 ampliar a rede de espaços públicos culturais, fortalecer o acesso à cultura e, no que diz respeito especificamente à economia criativa, focar no apoio à produção, comercialização, infraestrutura e capacitação. A divulgação da imagem da cidade no exterior se deu a partir de grandes eventos 
socioculturais ligados à economia criativa, como os desfiles das escolas de samba no Carnaval. No entanto, tal divulgação foi severamente prejudicada pela tentativa sistemática de depreciação de inúmeras expressões culturais da cidade do Rio de Janeiro pelo ex-prefeito Marcelo Crivella - como aquelas associadas à cultura afro-brasileira e à população LGBT+ - e os múltiplos impactos no campo da economia criativa da cidade por conta de medidas de distanciamento social, fechamento de espaços culturais durante a pandemia do novo coronavírus e não-realização de eventos culturais que são importantes para a economia da cidade, mas geram aglomerações. A crise econômico-financeira já havia reduzido o montante de recursos a serem utilizados na manutenção de equipamentos culturais que promovem a singularidade das regiões cariocas e o pagamento dos funcionários que trabalham nesses equipamentos. No âmbito dos eventos culturais, o ajuste fiscal promovido por Crivella afetou as finanças de alguns dos principais eventos culturais da cidade, como a Parada do Orgulho LGBTI+. Crivella foi acusado por grupos da sociedade civil de deixar suas convicções religiosas interferirem nas decisões administrativas (Jesus et al., 2019).

A economia criativa da cidade do Rio de Janeiro foi impactada de forma diferente pela pandemia do novo coronavírus. Muitos profissionais criativos perderam seus empregos devido à crise porque alguns projetos foram atrasados ou cancelados. Com o hiato de contratação, muitos profissionais de criação disseram que não conseguiriam viver muito tempo sem trabalho, embora muitos procurassem viver de suas economias ou da ajuda do governo. Por exemplo, a Lei Aldir Blanc - Blanc foi um dos primeiros artistas mortos por causa da pandemia - estipulou que o governo brasileiro repassasse três bilhões de reais aos estados e municípios para serem investidos em ações emergenciais de apoio ao setor cultural, incluindo o custeio de renda mensal emergencial para trabalhadores da cultura. A Lei permite que instituições financeiras federais criem linhas de crédito especiais e concedam condições especiais para renegociação de dívidas (SECEC-RJ, s.d.). Alguns setores criativos, como teatro, dança, entretenimento ao vivo, eventos, museus, galerias e patrimônio cultural tangível foram amplamente expostos à pandemia e sofreram perdas substanciais ao longo de 2020, o que levou vários empreendimentos à falência. Outros setores como moda, artes visuais, gastronomia e artesanato também tiveram perdas, mas se preparam para uma lenta recuperação com a reorganização de suas cadeias produtivas e a criação de produtos e serviços em resposta às mudanças de comportamento do consumidor com a incorporação de aprendizagem virtual, logística e métodos de entrega. Alguns setores da economia de baixo contato pareciam menos expostos à Covid-19, como gravação de música e rádio, produção de conteúdo digital e e-sports. O 
consumo de produtos desses setores manteve-se relativamente estável ou até cresceu (Jesus, 2020; Jesus et al, 2020).

A esta realidade soma-se um quadro preexistente de deficiências na gestão e a falta de conhecimento técnico nos órgãos fiscalizadores, que levam à decadência física e simbólica do patrimônio cultural da cidade. Particularmente no Centro do Rio, a degradação e a destruição do patrimônio histórico e a insegurança para novos investimentos diante da grave crise econômica se intensificaram. A preservação do patrimônio cultural é fundamental para o desenvolvimento de uma cidade criativa como o Rio de Janeiro, pois pode enfatizar as artes, serviços diferenciados e entretenimento para atrair profissionais criativos; reapropriar, restaurar e reabilitar o presente, visando a um futuro de relações sociais renovadas na cidade; e levar à apreensão de saberes tradicionais, transversais a diversos campos, buscando o desenvolvimento socioeconômico. No entanto, as deficiências na gestão e o escasso conhecimento técnico nos órgãos fiscalizadores levaram à decadência física e simbólica do patrimônio cultural da cidade. Além disso, o descaso e a depredação do patrimônio material e a desvalorização do imaterial podem ser indicativos da falta de um intenso processo de educação patrimonial (Jesus, 2017).

Quanto às evidências simbólicas, os atributos intangíveis após os Jogos Olímpicos de 2016 já indicavam níveis insatisfatórios de estima, admiração e confiança dos cariocas por uma marca de cidade de sucesso. Muitos moradores indicaram estar insatisfeitos com a cidade e consideraram a possibilidade de morar em outro lugar. Entre os principais motivos de ainda não terem se mudado, as principais causas mencionadas por esses moradores foram o medo de deixar o trabalho; a falta de dinheiro para cobrir os custos da mudança; a manutenção de vínculos com a família; a realização de estudos; e a presença de amigos na cidade. Entre os principais pontos negativos do Rio de Janeiro, os moradores apontaram a falta de segurança pública; as más condições de trânsito; o alto custo de vida; a poluição de rios, ar, mares e lagoas; e as condições precárias dos serviços em geral (Veja Rio, 2016). Com a pandemia da Covid19, houve um grande aumento na confiança dos brasileiros em geral - e dos cariocas em particular - em relação ao Sistema Único de Saúde (SUS). Uma razão para isso pode ter sido o maior conhecimento dos brasileiros em geral sobre o que é o sistema e quais são as suas atribuições. O relatório Quality of Life, da Teleport Cities, que avalia 266 cidades ao redor do mundo, produziu alguns resultados importantes. $\mathrm{Na}$ avaliação do custo de vida, a capital fluminense fica em $62^{\circ}$ lugar (de um total de 248 cidades avaliadas). Em relação a economia e tributação, a cidade cai no ranking, ocupando a $253^{a}$ posição entre 263 cidades e a $237^{a}$ entre 266 cidades, respectivamente. Os únicos destaques positivos são os de lazer e cultura (em que 
o Rio está em $18^{\circ}$ lugar, entre 264 cidades) e espaços ao ar livre, em $34^{\circ}$ lugar, entre 266 cidades (Teleport, 2020). A confiança dos empresários industriais mostrou 59,8 pontos em janeiro de 2021, uma redução de 0,6 pontos em relação ao último mês de 2020, após sete altas consecutivas. Tal queda se deve aparentemente ao ressurgimento dos efeitos da pandemia de Covid-19 (Firjan, 2021). Embora o relatório se refira ao estado do Rio de Janeiro, é possível supor que, na capital, a tendência se mantenha.

Houve iniciativas importantes para a promoção das conexões na cidade. Em setembro de 2017, os governos federal, estadual, municipal e a iniciativa privada divulgaram um calendário de eventos no estado e na capital durante o ano de 2018, com o objetivo de reverter a grave situação financeira e social. A tentativa de alavancar o turismo mostrou-se uma das principais iniciativas para aumentar a arrecadação de impostos e explorar as vocações socioeconômicas da cidade e do estado do Rio de Janeiro. O programa trouxe para o Rio de Janeiro eventos culturais, esportivos e corporativos com potencial impacto socioeconômico. Entre alguns dos principais eventos, destacam-se o Carnaval de Rua da cidade, os Desfiles das Escolas de Samba, a Temporada Internacional no Theatro Municipal, o Circuito Carioca de Moda, a Parada do Orgulho LGBTI-Rio, o Festival Anima Mundi, os X-Games e o Réveillon. A expectativa era a de que os eventos pudessem contribuir para a geração de espaços presenciais e virtuais que estimulassem conexões entre as pessoas e a cidade; entretanto, para que tais conexões ocorressem, seria necessário primeiro estabelecer um ambiente de segurança e confiança para que moradores e turistas pudessem circular pela cidade e ir a tais eventos, o que se tornou inviável com o aumento do número de crimes contra a vida e o patrimônio. Ao longo de 2020 e início de 2021, foi possível notar uma mudança dramática nas atividades relacionadas ao turismo, shows e aglomeração de pessoas, principalmente a partir de março de 2020, quando a quarentena motivada pela pandemia de Covid-19 fechou diversos outros estabelecimentos. Em maio de 2020, o subsecretário estadual de megaeventos, Ruan Lira, acreditava que seria possível realizar grandes eventos no Rio de Janeiro em meados de outubro/novembro, e possivelmente essa percepção foi compartilhada por muitos cariocas. Infelizmente, as autoridades cariocas decidiram adiar o Carnaval e depois cancelá-lo definitivamente em 2021, assim como a queima de fogos do Réveillon 2020/2021 em Copacabana, algo que nunca havia acontecido antes. Os blocos de rua do Rio também não desfilaram, em decisão ratificada em outubro de 2020 pelo presidente da Riotur, Fabrício Villa Flor, junto a médicos infectologistas, especialistas em segurança pública e representantes dos blocos de carnaval de rua. Além disso, 
muitos shows ao vivo foram substituídos por apresentações virtuais de artistas e bandas (Exame, 2020).

As potencialidades da Marca Rio são predominantemente baseadas em inovação e sustentabilidade. O desenvolvimento da inovação é fundamental para uma cidade criativa como o Rio de Janeiro, pois a ideia de inovação pode ser definida como a efetiva introdução e aplicação de processos e produtos inéditos em uma organização ou sociedade, destinados a beneficiar seus stakeholders, bem como indivíduos e a sociedade em geral. Pode ser uma resposta a mudanças no ambiente externo ou uma ação preventiva que influencia o ambiente em que se atua (West \& Anderson, 1996). Isso se mostra fundamental no contexto de crise sociopolítica e econômica em que a cidade se encontra, visando a realizar intervenções e medidas preventivas que revertam esse contexto. O Rio de Janeiro também pretende se posicionar como uma cidade sustentável, ou seja, uma cidade cujo governo esteja atento às necessidades presentes e às bases para as gerações futuras, implementando programas de redução da emissão de gases poluentes e despoluição de rios e lagos, além de iniciativas para buscar eficiência energética, melhor gestão hídrica, melhoria da mobilidade urbana e urbanização de comunidades mais pobres, por exemplo. No entanto, o Rio de Janeiro ainda apresenta desafios como a gentrificação e o reforço das assimetrias socioeconômicas. A atração de mais pessoas para a cidade nas últimas décadas tem sido acompanhada pelo aumento dos preços, maior competição por empregos e especulação imobiliária. Essa dinâmica repercute na falta de incentivos e subsídios para emprego e condições dignas de moradia para a população local, o que afeta diretamente o meio ambiente, com a ocupação irregular de terras em encostas e comunidades carentes. O Rio de Janeiro é vulnerável às mudanças climáticas, que se manifestam em enchentes, ondas de calor e impactos na infraestrutura, como deslizamentos de terra e danos à drenagem, estradas e redes de eletricidade, gás, telefone e internet. No contexto pós-olímpico, também é visível a crise no setor imobiliário, com excesso de oferta de imóveis residenciais e comerciais, bem como no setor hoteleiro. Embora o Rio de Janeiro seja dotado de inúmeras belezas naturais, a maioria dos moradores ainda vê que seus rios e lagos servem apenas como depósitos de lixo ou meros cenários de contemplação. Com o despejo de esgoto nas águas e a multiplicação de comunidades ao redor dos lagos - principalmente na Zona Oeste -, a degradação ambiental avança na cidade. As melhorias ambientais prometidas com a realização de megaeventos esportivos na cidade - como a despoluição da Baía de Guanabara nunca ocorreram (Freitas, 2013). 


\section{Considerações finais}

Para fortalecer a identidade da Marca Rio, foi apresentada uma análise focada nas suas dimensões físicas e simbólicas. As evidências físicas da marca são compostas por atributos relacionados às dimensões produtiva, política e histórico-cultural da marca da cidade, enquanto as simbólicas são formadas por atributos intangíveis, conexões com o lugar e potencialidades da marca. É possível afirmar que, visando a aumentar a percepção positiva da Marca Rio, seria fundamental ampliar os instrumentos políticos e sociais de monitoramento das ações policiais e conduzir casos de violação de direitos humanos às autoridades nacionais e internacionais responsáveis por essas questões para investigação e possível punição dos culpados de tais abusos. Essa medida poderia ser acompanhada pelo estímulo ao engajamento de grupos da sociedade civil organizada na formulação de políticas públicas municipais e no monitoramento das ações políticas e dos gastos das autoridades municipais, estaduais e federais, com vista à maior transparência pública. A maior articulação entre as políticas de defesa nacional e segurança pública é fundamental, principalmente no que diz respeito à ampliação do monitoramento das fronteiras do país e do estado do Rio de Janeiro, visando a coibir o tráfico de drogas e armas e combater o roubo de cargas. Vale destacar também o fortalecimento e a aceleração da discussão política sobre projetos federais, estaduais e municipais que gerem renda e emprego para populações de menor renda e abaixo da linha da pobreza, principalmente em setores ligados às vocações da cidade. Além disso, seria fundamental que o poder público se engajasse com o setor empresarial e o terceiro setor na formação de cidadãos para a inserção dessas pessoas em setores produtivos relacionados às vocações urbanas, com a utilização do conhecimento local na geração de renda e emprego. Em termos de estímulo à coesão social, seria importante ampliar a cooperação institucional entre os diferentes níveis de governo, o setor privado e os grupos organizados da sociedade civil na realização de eventos e estimular a diversidade de manifestações artísticas e culturais na realização desses eventos, que permitem a criação e consolidação de conexões entre as pessoas e a cidade e exploram seu potencial para o desenvolvimento da liberdade individual (Jesus, 2019).

Como pode ser visto na literatura sobre o assunto, as influências e os processos dinâmicos entre os componentes da identidade da marca abrangem a forma como uma marca de lugar é percebida (Jacobsen, 2012; Mariutti, 2019), pois também influenciam o branding de experiência (Mariutti, 2019). Esses temas dizem respeito às estratégias de cidades e nações, em termos de planejamento urbano e desenvolvimento regional. Nesse sentido, dada a atual 
competitividade entre cidades, regiões e países, as dimensões aqui consideradas fornecem outra forma de se compreenderem questões relacionadas a atributos sociais, econômicos e sustentáveis.

Este estudo é limitado por sua escala, pois o foco é apenas na cidade do Rio de Janeiro, e a abordagem é qualitativa. Futuras pesquisas poderiam considerar o uso de métodos de natureza quantitativa para obter achados generalizáveis. Além disso, o estudo de marcas de lugar por meio de escalas diferentes das cidades poderia ser realizado, para melhor compreender a identidade, a imagem e a reputação em outros níveis de dimensionamento do território.

\section{Referências}

Aitken, R., \& Campelo, A. (2011). The four R's of place branding. Journal of Marketing Management, 27(9-10), 913-933.

Barreira, G. (2021). Tribunal que julga impeachment de Witzel ouve testemunhas nesta quarta-feira. Retrieved from https://g1.globo.com/rj/rio-dejaneiro/noticia/2021/01/13/tribunal-que-julga-impeachment-de-witzel-ouve-testemunhasnesta-quarta-feira.ghtml. Access: June 19th, 2021.

Berrone, P. \& Ricart, J. E. (2016). IESE cities in motion index 2016. Navarra: Iese Business School, University of Navarra.

Betim, F. (2020). Flávio Bolsonaro é denunciado por lavagem de dinheiro e organização criminosa no caso da 'rachadinha'. Retrieved from https://brasil.elpais.com/brasil/202011-04/flavio-bolsonaro-e-denunciado-por-lavagem-dinheiro-e-organizacao-criminosa-nocaso-da-rachadinha.html. Access: June 19th, 2021.

Bowen, G. (2009). Document analysis as a qualitative research method. Qualitative Research Journal, 9 (2), 27-40. https://doi.org/10.3316/QRJ0902027

Braun, E. (2008). City Marketing: Towards an Integrated Approach. ERIM PhD Series in Research and Management, 142, Erasmus Research Institute of Management (ERIM), Rotterdam, Retrieved May 7, 2021 from http://hdl.handle.net/1765/13694

Braun, E. \& Zenker, S. (2010). Towards an Integrated Approach for Place Brand Management, 50th Congress of the European Regional Science Association: "Sustainable Regional Growth and Development in the Creative Knowledge Economy", 19-23 August 2010, Jönköping, Sweden, European Regional Science Association (ERSA), LouvainlaNeuve.

Caldwell, N. \& Freire, J. R. (2004). The differences between branding a country, a region and a city: Applying the Brand Box Model. Journal of Brand Management, 12 (1), 50-61.

Cheverton, P. (2012). Understanding Brands. Glasgow: Kogan Page. 
Coelho, H. \& Rodrigues, M. (2017). Governos e empresários anunciam calendário de grandes eventos para a cidade. Retrieved from https://g1.globo.com/rio-dejaneiro/noticia/prefeitura-do-rio-anuncia-calendario-de-grandes-eventos-para-acidade.ghtml. Access: June 23rd, 2021.

Delgado-García, J.B., de Quevedo-Puente, E., \& Blanco-Mazagatos, V. (2017). The impact of city reputation on city performance. Regional Studies, 52, 1098-1110.

https://doi.org/10.1080/00343404.2017.1364358

Diário do Rio (2021). Centro do Rio passa por crise sem precedentes. Retrieved from https://diariodorio.com/centro-do-rio-passa-por-crise-sem-precedentes/ . Access: June 19th, 2021.

Exame (2020). Carnaval de rua do Rio de 2021 é cancelado; blocos vão aguardar a vacina. Retrieved from https://exame.com/brasil/carnaval-de-rua-do-rio-de-2021-e-canceladoblocos-vao-aguardar-a-vacina/ . Access: June 19th, 2021.

Firjan (2021). Índice De Confiança Do Empresário Industrial Fluminense - Icei-Rj. Retrieved from https://www.firjan.com.br/publicacoes/publicacoes-de-economia/indice-deconfianca-do-empresario-industrial-fluminense-2.htm. Access: May 1st, 2021.

Franzen, G. \& Bouwman, M. (2001). The Mental World of Brands. Henley-on-Thames: Warc.

Freitas, C. (2013). Rio de Janeiro: cidade modelo de sustentabilidade? Retrieved from http://www.jb.com.br/rio/noticias/2013/12/01/rio-de-janeiro-cidade-modelo-desustentabilidade/. Access: June 23rd, 2021.

Gammelsæter, H. (2017). Media visibility and place reputation: does sport make a difference? Journal of Place Management and Development, 10 (3), 288-298. https://doi.org/10.1108/JPMD-01-2017-0004

G1 (2020). Entenda a investigação que levou Crivella à prisão. Retrieved from https://g1.globo.com/rj/rio-de-janeiro/noticia/2020/12/22/entenda-o-esquema-que-levou-aprisao-de-crivella.ghtml. Access: June 19th, 2021.

Grinberg, F. (2020) Covid-19: Fiocruz alerta que Saúde do Rio já está em colapso com novo avanço de casos. Retrieved from https://oglobo.globo.com/rio/covid-19-fiocruz-alerta-quesaude-do-rio-ja-esta-em-colapso-com-novo-avanco-de-casos-1-24777705. Access: June, 19th, 2021.

Hanna, S., Rowley, J., \& Keegan, B. (2021). Place and Destination Branding: A Review and Conceptual Mapping of the Domain. European Management Review, 18, 105-117, (202

Jesus, D. S. V. (2017). Saudade de mim: patrimônio cultural e economia criativa no Rio de Janeiro. In: J. L. Figueiredo \& D. S. V. Jesus (Org.). Cidades Criativas: Aspectos Setoriais e Territoriais, 157-177. Rio de Janeiro: E-Papers. 
Jesus, D. S. V. (2019). O Decreto No. 9.288 e a intervenção federal no Estado do Rio de Janeiro: motivações e repercussões político-sociais e econômicas. Revista de Direito da Cidade, 11(2), 194-214. https://doi.org/10.12957/rdc.2019.37571

Jesus, D. S. V. (2020). Necropolitics and Necrocapitalism: The Impact of COVID-19 on Brazilian Creative Economy. Modern Economy, 11 (6), 1121-1140.

https://doi.org/10.4236/me.2020.116082

Jesus, D. S. V. (2021). As If There Were No Tomorrow: New Year's CovidFests in Brazil. Sociology Study, 11(1), 33-36. https://doi.org/10.17265/2159-5526/2021.01.003

Jesus, D. S. V., Kamlot, D., \& Dubeux, V. J. C. (2020). Innovation in the 'New Normal? Interactions, the Urban Space, and the Low Touch Economy: The Case of Rio de Janeiro in the Context of the COVID-19 pandemic. International Journal Of Social Science Studies, 8 (5), 17-27. https://doi.org/10.11114/ijsss.v8i5.4900

Jesus, D. S. V., Kamlot, D., Dubeux, V. J. C., Reis, P. C., \& Robaina, D. T. (2019). "Olha que coisa mais linda, mais cheia de graça": a violência física e simbólica contra a mulher na Marca Rio (2016-2018). Caderno Espaço Feminino, 32(2), 250-279. https://doi.org/10.14393/CEF-v32n2-2019-13

Jones, J. (2004). A publicidade na construção de grandes marcas. São Paulo. Nobel.

Kamlot, D. (2012). Interferência do Estado na sociedade: uma visão de marketing social. Revista da ESPM, 19 (3), 78-83.

Kamlot, D. (2017). Resiliência organizacional e marketing social: uma avaliação de fundamentos e afinidades. Cadernos EBAPE. BR. 15(n. spe), 482-495. https://doi.org/10.1590/1679-395160269

Kamlot, D. \& Fajardo, B. G. (2019). Marketing. Rio de Janeiro: FGV.

Kamlot, D. \& Jesus, D. S. V. (2020). Uncertainty during Covid-19 Outbreak in Brazil: Clashes between the President and Governors. International Journal of Humanities and Social Science, 10 (6), 36-41. https://doi.org/10.30845/ijhss.v10n6p5

Kapfereer, J-N. (2008). Strategic Brand Management: Creating and Sustaining Brand Equity Long Term. London: Kogan Page.

Kotler, P. Marketing essencial. (2012). São Paulo: Prentice Hall

Kotler, P. \& Gertner, D. (2002). Country as a brand, product, and beyond: A place marketing and brand management perspective. Journal of Brand Management, 9 (4-5), 249-261. https://doi.org/10.1057/palgrave.bm.2540076

Mariutti, F. G. (2019). Fundamentos teóricos sobre marketing de lugar, gestão de marca de lugar e valor de marca de lugar. Comunicação \& Mercado, 6 (14), 163-184. 
Mariutti, F.G. \& Giraldi, J.M.E. (2021). Branding cities, regions and countries: the roadmap of place brand equity. RAUSP Manag. J., 56 (2), 202-216,

Moura, L. (2021). O que esperar do desemprego no Estado do Rio em 2021? Retrieved from https://odia.ig.com.br/economia/2021/01/6060648-o-que-esperar-do-desemprego-noestado-do-rio-em-2021.html. Access: June 19 ${ }^{\text {th }}, 2021$.

Nunes, G. \& Haigh, D. (2003). Marca: valor do intangível. São Paulo: Atlas.

Ocke, M. A. M. \& Ikeda, A. A. (2014). Marketing de lugar: estado da arte e perspectivas futuras $R$. Adm., 49 (4), 671-683. https://doi.org/10.5700/rausp1176

Reis, P. C. (2018). A Marca da Cidade: Reflexões e Proposições para Construção e Gestão de Marcas de Cidades. O Caso do Rio de Janeiro. Curitiba: Appris.

Reputation Institute. (2014). 2014 City rep trak: the world's most reputable cities. Retrieved from https://www.internations.org/magazine/the-world-s-most-reputable-cities-18848 Access July 13 ${ }^{\text {th }}, 2021$.

Ries, A. \& Ries, L. (2009). The 22 immutable laws of branding: how to build a product or service into a world-class brand. New York: HarperCollins Publishers.

Ritchie, J. R. B. \& Ritchie, R. J. B. (1998). The Branding of Tourism Destinations: Past Achievements and Future Challenges. Proceedings of the 1998 Annual Congress of the International Association of Scientific Experts in Tourism, Destination Marketing: Scopes and Limitations, edited by Peter Keller. Marrakech: International Association of Scientific Experts in Tourism, 89-116.

Saffron B. C. (2013) The Saffron European City Brand Barometer: revealing wich cities get the brands they deserve. Jeremy Hildreth. London: Saffron Brand Consultants

Sampaio, R. (2013). Propaganda de A a Z. 3.ed. Rio de Janeiro. Campus.

Sampaio, R. (2006). Ranking da Interbrand destaca Coca-Cola e Google. Retrived May 10, 2020, from www.portaldapropaganda.com/marketing/2006/07/0002,

Sanny, L. et al. (2020). Purchase intention on Indonesia male's skin care by social media marketing effect towards brand image and brand trust. Management Science Letters, 10, 2139-2146.

Schiffman, L.G. \& Kanuk, L.L. (2009). Consumer Behavior. London: Prentice Hall. SECEC-RJ. (n.d.). Aldir Blanc - Editais. Retrieved from http://cultura.rj.gov.br/lei-aldirblanc-editais/. Access: June 19th, 2021.

Severino, A. J. (2018). Metodologia do trabalho científico. São Paulo: Cortez.

Skinner, H. (2011). In search of the genius IOCI: The essence of a place brand. The Marketing Review, 11 (3). 281-292. 
Teleport (2020). Quality of life in Rio de Janeiro. 2020. Retrieved from https://teleport.org/cities/rio-de-janeiro/ Access: February 23rd, 2021.

Tybout, A.M. \& Carpenter, G.S. (2013). Criação e gestão de marcas. In: Calder, B.J. \& Tybout, A.M. (Orgs.). Marketing. São Paulo: Saraiva, 119-153.

Van den Berg, L. \& Braun, E. (1999). Urban competitiveness, marketing and the need for organising capacity. Urban Studies, 36 (5-6), 987-999.

https://doi.org/10.1080/0042098993312

Veja Rio (2016). Pesquisa revela que $71 \%$ dos cariocas estão insatisfeitos com a cidade. Retrieved from https://vejario.abril.com.br/cidades/pesquisa-revela-que-71-dos-cariocasesta-insatisfeito-com-a-cidade/. Access: June 23rd, 2021.

West, M. A. \& Anderson, N. (1996). Innovation in Top Management Teams. Journal of Applied Psychology, 81 (6), 680-693. https://doi.org/10.1037/00219010816680

Zenker, S. (2011). How to catch a city? The concept and measurement of place brands. Journal of Place Management and Development, 4(1), 40-52. https://doi.org/10.1108/17538331111117151 